October 2018

MATUS SENAJ

ZUZANA SI EBERTOVA

NORBERT SVARDA

J ANA VALACHYOVA 


\title{
THE EVALUATION OF FISCAL CONSOLIDATION STRATEGIES
}

\author{
CELSI Discussion Paper No. 51 \\ October 2018
}

\section{Matus Senaj}

Council for Budget Responsibility

\section{Zuzana Siebertova}

Council for Budget Responsibility

\section{Norbert Svarda}

Council for Budget Responsibility

\section{Jana Valachyova}

Council for Budget Responsibility

The Central European Labour Studies Institute (CELSI) takes no institutional policy positions. Any opinions or policy positions contained in this discussion paper are those of the author(s), and not those of the Institute.

The Central European Labour Studies Institute (CELSI) is a non-profit research institute based in Bratislava, Slovakia. It fosters multidisciplinary research about the functioning of I abour markets and institutions, work and organizations, business and society, and ethnicity and migration in the economic, social, and political life of modern societies.

CELSI Discussion Paper series is a fIagship of CELSI's academic endeavors. Its objective is the dissemi nation of fresh state-of-the-art knowledge, cross- fertilization of knowledge and ideas, and promotion of interdisciplinary dialogue about l abour markets or broader labour issues in Central and Eastern Europe. Contributions fromall social science disciplines, including but not limited to economics, sociology, political science, public polic social anthropology, human geography, demography, I aw and social psychology, are welcome. The papers are downloadable from http:/l www. celsi.sk. The copyright stays with the authors.

\section{Central European Labour Studies Institute (CELSI)}

$\begin{array}{ll}\text { Zvolenská } 29 & \text { Tel/Fax: +421-2-20735767 } \\ 821 \text { og Bratislava } & \text { E-mail: info@celsi.sk } \\ \text { Slovak Republic } & \text { Web: www. celsi.sk }\end{array}$


CELSI Discussion Paper No. 51

October 2018

\section{ABSTRACT}

\section{The Evaluation of Fiscal Consolidation Strategies}

In this paper, we present a framework and perform an assessment of different fiscal consolidation strategies both on the revenue as well as on the expenditure sides of the budget in the context of slovakia. The model we use for simulations is a behavioural general-equilibrium what_if model. We analyse the simulated impacts of consolidation strategies on growth and on fiscal balance (both in short- and 1ong- term). The microsimulation approach allows us also to evaluate the distributional impacts. In addition, the approach permits to compare the statutory with the resulting tax incidence in the long-run. We simulate strategies based on taxing labour income, taxing consumption as we11 as cutting expenditures on social transfers. We document that corporate and labour taxes are more unfavourable to output growth, while consumption taxes belong to less damaging instruments for consolidation. We show that spending cuts may promote employment and are not detrimental to output growth.

Keywords: microsimulation, general equilibrium, tax and transfer system, government policy

JEL Classification: C63, H22, 138

\section{Corresponding Author:}

Zuzana Si ebertova

Council for Budget Responsibility

siebertova@rrz.sk 


\section{INTRODUCTION}

Although noticeable improvements have been made in the aftermath of the global economic crisis and recession of the late 2000s, many countries still face considerable budget deficits and growing public debts. In response to these undesirable developments, most governments in the advanced economies have already introduced extensive strategies to achieve fiscal consolidation to alter this unsustainable development. An important issue related to fiscal consolidation, or in broader sense any reform related to public financing, is how different reform strategies will affect future economic performance of the country.

The analysis of short- and long-run effects of fiscal consolidations has attracted a lot of attention in the academic literature and this topic is a crucial issue also for policy makers. Most of the academic papers look at the aggregate economic implications, like the overall impact on employment or output growth, but usually do not take into account implied distributional effects or the influence on income inequality. Several these studies present evidence that spending based adjustments, like cuts in government spending or transfers to households (including pensions and social benefits), are less detrimental to future economic activity than increasing taxes. A survey of this strand of literature can be found in Alesina and Ardagna (2010). More evidence reinforcing and supporting these ideas can be found in IMF (2010) or Alesina and Ardagna (2012). On the other hand, Figari et al. (2015) use static microsimulations to show the importance of the interactions between various consolidation strategies and the income distribution. Inappropriately, this aspect has been often overlooked in the macroeconomic literature. They find that as an immediate effect of the consolidation, richer households tend to bear greater burden when taxes are increased, while low-income households are more affected by spending cuts. As an alternative approach, Cournede et al. (2013) present a qualitative framework designed to rank fiscal consolidation instruments. The ranking reflects some kind of compromise between adverse side-effects of consolidation on growth (short- and long-term), income inequality as well as on external imbalances.

In this paper, we present results of a quantitative evaluation of fiscal consolidation strategies in the context of Slovakia. Strategies are assessed within the framework of a behavioural general equilibrium model. This approach utilizes microsimulation techniques that allow to simulate the Slovak tax and benefit system changes in fine detail (see our related paper by Siebertova et al., 2016) and to quantify their impact on individual and household income distribution. The model is behavioural, so changes in individual attitudes conditional on applied fiscal consolidation 
instruments (within tax and transfer system) are taken into account. Modelling the labour supply at the extensive margin is detailed in our related analysis by Senaj et al. (2016). Based on the macro part of the model, described in Horvath et al. (2015), the long-run effects on the aggregate economy can be evaluated (in particular, the impact on output growth or employment).

The consolidation instruments that we consider in this paper are policies that are intended to affect governments' primary revenues and spending. More specifically, we examine how changes in direct and indirect taxation and in social transfers to households affect the aggregate economic performance, as well as income distribution and inequality. This is the practical advantage of combining empirical micro and theoretical macro blocks of our model, as it allows to evaluate these impacts in a unified framework. We provide an assessment of two sets of policies.

First, we define the benchmark scenarios to demonstrate how our simulation model works and through which specific channels the results are obtained. These consolidation strategies involve altering single parameter of the tax and transfer system. We identified marked heterogeneity in terms of magnitude, composition as well as short- and long-run effects of fiscal consolidation. The approach that we are using allows us to consider the interactions between the setup of consolidation instruments and households' distribution of income. We show that increase in consumption taxes is less detrimental to output growth than increase in labour taxes. Due to the statutory settings of the Slovak tax system, lower-income households tend to bear greater burden when income tax allowances are reduced, while richer households are more affected by tax rates increases. Spending cuts reduce directly households' disposable income and thus are more likely to influence the lower part of the income distribution. Considerable labour supply reaction at the extensive margin increases employment in the long-run, and we show that spending cuts strategies do not destruct output growth.

We address an important question of how to provide an appropriate assessment of the simulation results. This we understand as a fundamental issue, if the presented approach should be used as an analytical tool in the actual practice of policy makers or analysts in general. Therefore, to evaluate fiscal and economy wide impacts of reform strategies in monetary amounts (euros), we use scaling factors that provide an adjustment of the differences between simulated outcome from the model and the official statistics.

The structure of the paper is the following. In section 2, methodology is summarized and the valuation of the simulation results is discussed. Section 3 provides an evaluation of the 
consolidation scenarios. In particular, we discuss their setup, common features, distributional and economic implications. Finally, section 4 concludes.

\section{METHODOLOGICAL FRAMEWORK}

In this paper consolidation scenarios, designed as a tax and transfer system reforms, are evaluated in the framework of the general equilibrium behavioural microsimulation model. The approach taken allows us to provide an assessment of different impacts of the selected fiscal instruments. First, immediate fiscal effects are evaluated by using the static microsimulation model of the Slovak tax and transfer system SIMTASK. The behavioural reaction, after individuals have adjusted their behaviour to the new environment after the reform scenario has been implemented, is simulated using a labour supply model. Finally, the long-run effects are assessed using the micro-macro simulation model what_if that is estimated and calibrated for Slovakia. Long-run in our model stands for an appropriate time frame that permits the effects of the policy measures fully to work themselves through the economy. Further details on the Slovak tax and transfer system, the labour supply model and on what_if macro model is provided in Appendix A.

\subsection{A microsimulation model and data}

The essential building block of the modelling framework is SIMTASK, a microsimulation model of the Slovak tax and transfer system described in detail in Siebertova et al. (2016). Simulations covered by SIMTASK include direct taxes (labour and capital income taxes), social and health insurance contributions paid both by employees, self-employed and employers. Simulated transfers include most family related benefits, unemployment and material need benefit. Besides simulating labour taxes, model also includes the module that simulates indirect value-added tax liabilities of households.

As an underlying dataset, the microsimulation block uses the SK-SILC survey data. SK-SILC is the national version of the Statistics on Income and Living Conditions that is collected on an annual basis by the Statistical Office of the Slovak Republic. It contains cross-sectional data on individuals and households and comprises detailed information on different sources of income and socio-demographic characteristics that are needed in the simulations. SK-SILC does not contain information on expenditures that is essential for the simulations of value added tax. Thus, a combined micro-level dataset that integrates information on disposable income and expenditures of Slovak households has been created. Households' expenditures reported in the Slovak Household Budget Survey dataset have been imputed to SK-SILC dataset by estimating 
parametric Engel curves, adopting the approach of Decoster et al. (2014). The imputed expenditures are then used to estimate the value added tax liabilities of households.

The most recent SK-SILC dataset available to us at the time of writing corresponds to the income reference period 2015. Since the baseline year in our study refers to 2018, the input dataset has been modified such that the selected income variables were uprated by the corresponding growth factors. However, demographic variables are fixed to values referring to 2015.

\subsection{A behavioural model}

In the microeconomic part of the model, the labour supply response of individuals to changes in direct and indirect taxes, social security contributions and transfers is simulated. The behavioural labour supply shock on the individual level consists of two components - response at the extensive (decision to participate in the labour market) and at the intensive margin (effective hours worked conditional on the decision to work).

The extensive margin response on the fiscal consolidation strategy is evaluated as the change in the individuals' probability of being economically active. Using the extended standard labour supply model presented in detail in our related paper by Senaj et al. (2016), the probability of being economically active is estimated by a probit model, where net income and social transfers received by individuals and other household members, as well as socio-demographic characteristics of individuals are considered simultaneously. In this framework, the decision of the individuals on participation in the labour market is examined by comparing two states - being economically active and being inactive. Within this approach, two fundamental variables are created, namely the so called "financial gains-to-work" and non-labour income for every individual. The financial gains-to-work is constructed as the difference between net wage and difference in received social transfers when working and not working.

Within the utility-maximization framework, it can be shown that individual decisions on consumption and leisure are altered equivalently by income and consumption taxes. Basically, both taxes reduce motivation to work. While income tax decreases the net labour income, consumption tax reduces the real disposable income. The concept used allows us to consider also the indirect consumption tax burden of households - such that both financial gains-to-work and non-labour income are adjusted by households' effective value added tax rate. For the construction of these variables (gains-to-work, non-labour income and effective households' VAT rate), the microsimulation tool SIMTASK is used. Afterwards, VAT-adjusted financial 
gains-to-work and non-labour income is evaluated for every individual both in baseline and in consolidation scenario. Participation effect of the consolidation strategy is then given as the change in individual participation probabilities evaluated in baseline and scenario cases.

The intensive margin response is the second component concerning the supply of work. Conditional on being employed, it is given as the change in the effective hours worked and can be expressed as a function of marginal and average effective tax rates and income growth.

\subsection{A long-run model}

The framework that we use for long-run evaluation of fiscal consolidation strategies is the what_if model presented in detail in Horvath et al. (2015). In general, the what_if model consists of two main blocks, the behavioural microsimulation one described above and a theoretical macroeconomic part. There is a bidirectional link between the macro model and microsimulation. Such approach is known as a top-down/bottom-up approach in the microsimulation literature and is used mainly as a combination of CGE and microsimulation models (see Cockburn et al., 2014 for the recent discussion on the topic).

An iterative algorithm is used to solve for the long-run equilibrium. The aggregate labour supply shock that results from individual responses on the extensive and intensive margins in the micro block of the model is embedded into the macro block, replacing a theoretical labour supply relationship. More specifically, three variables from micro part enter to macro part: the employment rate, the effective labour supply and the social security contributions paid by employers. In the macro part the optimizing firms react to the changed behaviour of individuals such that they adjust wages. This translates into a changed aggregate level of wages that are transmitted back into the microsimulation block where the labour income of every employed person is updated and a new labour supply shock is generated. The whole process is repeated until the convergence is reached.

The theoretical macroeconomic model is a neo-classical model of a small open economy extended with search \& matching frictions. The economy consists of infinite number of profitmaximizing firms. The model employs CES-type production function that combines capital and labour to produce a homogenous good. We assume that representative firm faces besides labour and capital costs also costs related to hiring employees. It is assumed that the process of searching for new employees is costly and for the unemployed it takes time to be matched to a new job. The standard Cobb-Douglas production function is used to match the unemployed and the vacancies. Thus, the model is consistent with the existence of involuntary unemployment. 
Due to high openness of the Slovak economy, the capital supply is assumed to be exogenous, capital is provided by the international capital market. In order to analyse the corporate income tax, we assume that accounting profit of firms equals to output minus labour and hiring costs (Anagnostopoulos et al., 2014). Consequently, the effective tax rate is applied to accounting profit and corporate tax liability is simulated.

\section{$2.4 \quad$ Scaling of simulated results}

Finally, to provide an appropriate assessment of simulation results, conceivable valuation methods should be applied. Results from the policy simulation models are usually defined in terms of (percentage) changes of tested scenarios to the pre-defined baseline. Baseline results are often presented as a direct output from the simulation model and thus might not correspond to the observed economic reality in terms of quantitative volumes of fiscal revenues from taxes or expenditures on social transfers. If this is the case, simulation results should be interpreted such that they document the channels and the relations within the model.

In the alternative validation scheme, simulated outcome from the micro part of the what_if model in the baseline is re-scaled to match the official statistics. The scaling coefficient for every instrument is computed as the ratio of the aggregate official statistics to the aggregate outcome from the model (detailed values are documented in Table 1). Since the baseline year in our analysis is 2018, predictions from the government budget proposal are used as the official statistics. Then the monetary effect (in euros) of the change is computed as the difference between re-scaled scenario and baseline values.

The scaling factors represent the extent to which household survey data fit to national aggregates. Direct taxes from labour and most social transfers are almost fully covered by our tax-benefit microsimulation model SIMTASK, so the corresponding scaling factors are reasonably close to one. However, the indirect value added tax is not completely covered in our model for two reasons. First, in our modelling framework the consumption of private households is simulated, so the consumption and VAT payments made by enterprises or public sector are outside the scope of the model. The second reason is that the household surveys significantly underestimate aggregate disposable income and consumption in the economy by $40-50 \%$, once compared to national accounts statistics (see the discussion in Fesseau et al. (2013) on the differences between micro and macro data sources). Thus, to evaluate economy wide impacts of consolidation strategies on the revenue from value added tax in the context of Slovakia, the simulated effect must be almost doubled (detailed in our related discussion study by Siebertova et al., 2018). 
Moreover, the usage of a scaling coefficient depends on the consolidation instruments applied in a particular scenario. In case when the consolidation includes direct changes in the value added tax rate, the scaling factor considers, in addition, the effect of tax rate change outside the households' sector. Specifically, the adjustment is provided for value added tax gained from gross fixed capital formation and public-sector consumption.

Table 1: Scaling of the simulation results

\begin{tabular}{|c|c|c|}
\hline Consolidation instrument & $\begin{array}{l}\text { Scaling } \\
\text { coefficient }\end{array}$ & Source of the official statistics for 2018 \\
\hline Personal income tax & 1.17 & Committee for the tax forecasts (Ministry of Finance) \\
\hline $\begin{array}{l}\text { Social and health insurance } \\
\text { contributions }\end{array}$ & 1.04 & Committee for the tax forecasts (Ministry of Finance) \\
\hline Social transfers & 1.07 & Information system on Government Budget \\
\hline Value added tax & 1.97 & $\begin{array}{l}\text { Committee for the tax forecasts (Ministry of Finance) } \\
\text { When scaling the VAT, only the part paid by } \\
\text { households is considered (estimated as the } 87 \% \text { of the } \\
\text { total volume). }\end{array}$ \\
\hline
\end{tabular}

Note: Scaling coefficient is given as the ratio of the official statistics to simulated outcome from the model. Official statistics for every consolidation instrument is a forecasted value.

\section{EVALUATION OF CONSOLIDATION STRATEGIES}

In the framework of the general-equilibrium model, we provide an assessment of the impact of selected consolidation instruments on short- and long-term fiscal stance, long-term growth and income inequality. The microsimulation approach allows us to evaluate changes in measures such as average and marginal effective tax rates (AETR and METR, respectively) or disposable income at an individual and households' level. We discuss how to provide a credible valuation and interpretation of the simulation results based on the outcomes from the model. As a baseline year for our analysis, the statutory settings of the tax and transfer system in Slovakia valid from 2018 are fixed.

In the analysis, we consider benchmark scenarios, which are defined as consolidation strategies altering only one parameter of a tax and transfer system. They demonstrate how our simulation model works and through which specific channels are the results obtained. We evaluate the strategies of fiscal consolidation both on the revenue as well as the expenditure sides of the budget. On the revenue side, we consider consolidation through increasing different direct and indirect taxes: the personal income tax, the corporate income tax and the value added tax. Also, changes in health insurance contributions paid by employees and employers are assessed. On the 
expenditure side, child tax credits along with a reduction of family related transfers are evaluated as well as a decrease in material need benefits.

The $w_{\text {_h }}$ hat if model is utilized to provide an assessment of the proposed consolidation strategies. First, we look at static or the "day-after" effect of the applied fiscal instruments. In particular, change in individual tax burden and aggregate fiscal effect is assessed under the assumption that people do not change their behaviour. However, the size of the fiscal effect is influenced by the behavioural adjustment to the changes induced after the consolidation measures are applied. This implies that consolidation instruments might affect the motivation to work, which translates into labour supply changes. By behavioural response we denote the effects including the reaction of labour supply to reform scenarios. In the long term, employers adjust gross wages as a reaction to labour supply changes as well as to the changes in their labour (employers' SIC and HIC), capital and hiring costs. Thus, the new economy wide equilibrium wage level is determinative to longterm fiscal revenues. As a result, the new equilibrium level of labour and capital is determinative to the long-term growth of GDP.

The detailed results of short-run, behavioural and long-run effects are summarized in Tables B.11 to B.1-3 in the Appendix, where the direct output from the model is introduced. In addition, Tables B.2-1 to B.2-3 in the Appendix present the re-scaled monetary effects of changes.

\subsection{Taxing labour income}

The first set of consolidation scenarios is related to labour income taxation. In the first two scenarios, the personal income tax rate is increased: in the first one the standard tax rate is increased by 1 percentage point, while in the second the one tax rate is introduced. In the third scenario, individual tax burden is increased through the reduction in tax allowances. The more detailed setup of the underlying baseline and proposed scenarios is presented in Table 2 .

When the consolidation is driven by an increase in labour taxes, employees bear the statutory burden. In the short term, the decrease in after-tax wages leads to a decrease in disposable income and translates into lower consumption. Consequently, the revenue from value added tax paid by households' declines. The parametric change in the tax rate determines the size of the effect: compared to 1 p.p. increase in the tax rate, the triple size increase of parameter in the onetax rate scenario leads to the total fiscal effect of triple size.

Labour supply response in all three scenarios is driven by decreased motivation to work. However, distributional effects differ (see Table B3 in the Appendix). When the tax allowances 
are reduced, mainly low-income individuals are affected. On the other hand, an increase in the tax rate in the first and second scenario affects more those with higher income. This arises from the fact that the effect of the tax rate increase is offset by applying tax allowances, which gradually decrease with income.

Table 2: Description of benchmark scenarios

\begin{tabular}{|c|c|c|}
\hline Scenario name & Actual/baseline legislation & Simulated policy change in scenario \\
\hline \multicolumn{3}{|c|}{ Taxing labour income } \\
\hline $\begin{array}{l}\text { PIT - } 1 \text { p.p. } \\
\text { increase in the } \\
\text { standard rate }\end{array}$ & $\begin{array}{l}\text { Two tax rates of personal income tax } \\
\text { apply: } \\
-19 \% \text { levied on yearly income up to } \\
35268 € \\
-25 \% \text { levied on income exceeding } \\
35268 €\end{array}$ & $\begin{array}{l}\text { The standard rate is increased from } \\
19 \% \text { to } 20 \% \text {. }\end{array}$ \\
\hline $\begin{array}{l}\text { PIT - One tax } \\
\text { rate }\end{array}$ & & $\begin{array}{l}\text { Introduction of one tax rate of } 22 \% \text {. } \\
\text { Basic and spouse tax allowances apply. }\end{array}$ \\
\hline $\begin{array}{l}\text { PIT - Decrease } \\
\text { in tax allowances }\end{array}$ & $\begin{array}{l}\text { Basic and spouse tax allowance up to } \\
3830 € \text { yearly (for each) can be } \\
\text { deducted from individual taxable } \\
\text { income. }\end{array}$ & $\begin{array}{l}\text { Basic and spouse tax allowance up to } \\
3630 € \text { yearly (for each) can be } \\
\text { deducted from individual taxable } \\
\text { income. }\end{array}$ \\
\hline \multicolumn{3}{|c|}{ Taxing consumption } \\
\hline $\begin{array}{l}\text { VAT - } 1 \text { p.p. } \\
\text { increase in the } \\
\text { standard rate } \\
\text { VAT - abolition } \\
\text { of the reduced } \\
\text { rate }\end{array}$ & $\begin{array}{l}\text { The standard rate is set to } 20 \% \text {, the } \\
\text { reduced rate } 10 \% \text {. A number of } \\
\text { goods are exempt from the tax base. }\end{array}$ & $\begin{array}{l}\text { The standard rate is increased to } 21 \% \text {. } \\
\text { The reduced rate is abolished, all goods } \\
\text { are taxed at the standard rate } 20 \% \text {. }\end{array}$ \\
\hline \multicolumn{3}{|c|}{ Payroll taxes: employees vs. employers } \\
\hline $\begin{array}{l}\text { HIC - } 1 \text { p.p. } \\
\text { increase in the } \\
\text { rate paid by } \\
\text { employers }\end{array}$ & $\begin{array}{l}\text { Health insurance contributions: } \\
\text { - 4\% employees } \\
\text { - } 10 \% \text { employers }\end{array}$ & $\begin{array}{l}\text { Increase of HIC paid by employers to } \\
11 \% \text {. }\end{array}$ \\
\hline $\begin{array}{l}\text { HIC - } 1 \text { p.p. } \\
\text { increase in the } \\
\text { rate paid by } \\
\text { employees }\end{array}$ & & $\begin{array}{l}\text { Increase of HIC paid by employees to } \\
5 \% \text {. }\end{array}$ \\
\hline \multicolumn{3}{|c|}{ Taxing firms } \\
\hline $\begin{array}{l}\text { CIT - } 1 \text { p.p. } \\
\text { increase in the } \\
\text { rate }\end{array}$ & Effective tax rate set to $19.5 \%$ & Effective tax rate increased to $20.5 \%$ \\
\hline
\end{tabular}

In the long-run, labour supply at the extensive margin decreases in all three scenarios (see Table B4 in the Appendix). In the tax rate change scenarios labour supply reacts at the intensive margin as well, since higher income individuals are affected. This contributes to the overall effective labour decrease in all three scenarios. Firms react to the decline in labour supply by raising wages 
which results into higher attractivity of being economically active. The highest decrease of labour supply occurs in the case of one-tax rate scenario and it also drives the highest increase in gross wages. A drop in effective labour goes hand in hand with a drop in the output of the economy. Lower output and higher labour costs result into the decrease of profits. Thus, the revenue from corporate income tax falls. Note that in the long-run the tax burden is distributed and falls partly also on employers. On the contrary, thanks to the growth in income base, the revenue from payroll taxes rises. When it comes to the inequality measures, we can see that in the tax rate change scenarios income inequality decreases, while progressivity of the tax system raises. These effects are reversed when tax allowances are reduced.

\subsection{Taxing labour income vs. taxing consumption}

The next set of consolidation scenarios concern taxing consumption instead of labour income. We consider 1 p.p. increase in the standard rate of value added tax and the abolition of reduced rate of value added tax (the setup of scenarios is detailed in Table 2). In order to study the effects on households' budget, we define similarly like Pestel and Sommer (2017) a quantity called postVAT income that equals to household disposable income minus paid VAT. It can be understood as the virtual monetary amount left for the consumption after VAT has been paid. Both, increase in income and consumption taxes lead to a drop in post-VAT income of households. While income tax rate growth reduces net wage, the consumption tax reduces real value of net earnings and social transfers. Summing up, the motivation to work of individuals is reduced by both forms of taxation. On the demand side, the firms react to decline in employment by raising wages, their labour costs increase and the overall output decreases.

The microsimulation approach allows us to consider in detail the effects of different forms of taxation on different population subgroups. Income tax system in Slovakia with two tax rates and a gradual phase-out of tax allowances is a progressive system. On the contrary, value added tax, when measured as a percentage of disposable income, exhibits a clearly regressive pattern (see Table 2.1 in OECD, 2014). When the behavioural reaction of individuals in the two scenarios of 1 p.p. increase is compared, in the scenario with income tax rate increase, mainly higher-income groups react and reduce their motivation to work. On the other hand, when value added tax is increased, the motivation to work of low-income groups decreases more (see Table B3 in the Appendix). Our empirical results confirm progressive pattern of income tax system and a regressive pattern of value added tax. The overall small magnitude of estimated changes depends on the statutory settings of the Slovak tax system. 
Comparing the long-run effects of the two sets of scenarios, labour as well as output face greater decrease when income tax is raised (detailed in Table B4 in the Appendix). The results gained from our model thus confirm an indication often discussed in the economic literature that capital/corporate and labour taxes are most detrimental to output growth, while consumption and property taxes belong to less damaging instruments for consolidation. For the discussion and useful references, see European Commission (2015b).

\subsection{Switching the tax burden - employers vs. employees}

The next topic we discuss is the distribution of the tax burden between employers and employees. We define two consolidation scenarios increasing the rate of health insurance contributions (HIC) by 1 p.p. either at the side of employees or employers. HIC should be understood as a form of labour taxation as they are the compulsory payments, guaranteeing an access to the full utilization of public healthcare. Since statutory tax incidence is in the former scenario born by employees and in the latter by employers, it is interesting to see the resulting economic incidence.

The immediate, or "the day-after" effect on the total revenues from HIC is of the same magnitude in both scenarios. However, the total fiscal impact is different. In the case of scenario increasing HIC for employees it is offset by the drop-out in the revenues from personal income tax and value added tax. Since the work incentives of employees are reduced, the immediate behavioural reaction of labour supply is present in this scenario (see Table B3 in the Appendix). Again, the firms react to reduced labour supply by increasing the wages.

On the other hand, in the case of scenario increasing HIC for employers, the total fiscal impact is offset by the drop-out in the revenues from corporate income tax. In this scenario labour supply in the short-run does not react. In the long-run, the firms, facing higher statutory labour costs, maximize their after-tax profits. Therefore, firms significantly reduce wages keeping their unit labour costs unchanged. This implies the switch of the tax burden, statutorily laid on employers, to employees. Overall, the employment and effective labour falls, which leads to the decline in output.

Classical models of labour market assume, that the side of the market, on which a tax is levied, does not affect its economic incidence. This implies that irrespective of which side of the market is tax levied on, the costs of the employer and the net wages received by the employees would adjust in the same way. However, there is no consensus of empirical works whether the "invariance of incidence proposition" holds (for the discussion and useful references see 
European Commission, 2015a). Our results show, for both analysed scenarios in the long-run a decline of net wages of employees and an increase in unit labour costs. Thus, confirming the adjustment process in the same direction. However, the magnitude differs, the impact on economy being larger in the scenario when the burden is statutorily increased for the employees.

The economic incidence, or, in other words the extent to which workers or employers bear the burden of labour taxation, is a function of labour supply and demand elasticities. Thus, in the long-run, relative size of elasticities of labour supply and labour demand determine the economic incidence. In our model, the elasticity of labour supply is estimated directly from microdata, while the degree of responsiveness of labour demand stems from the way how the macro-part is modelled and calibrated (e.g. involuntary unemployment). The results of analysed scenarios imply that 1 p.p. increase in the tax burden translates into the drop in net wages of employees by 0.4 $0.5 \%$. This holds, irrespective of the instruments applied (personal income tax rate or health insurance contributions either at the side of employees or employers). In both scenarios, the output of the economy decreases and net profits of firms decline, which confirms sharing the tax burden between the two sides.

\subsection{Taxing employers}

In the previous scenario, tax burden of employers was increased through the increase in labour costs. In the next scenario, we consider 1 p.p. increase in the corporate income tax (CIT) rate, which would decrease after-tax profits of the firms.

As a common feature, both scenarios show positive total fiscal effect, although the revenues from increase of HIC are higher than those from increase of CIT. In both cases, the statutory incidence is on the employers' side, thus initiating no immediate behavioural reaction of the labour supply. However, in the long-run, employers react differently and the tax burden is distributed. In the case of scenario increasing HIC, the employers aiming to reduce labour costs decrease gross wages. It turns out, that the employers shift the tax burden to employees (lower net wages). In case of the scenario increasing CIT rate, the employers decrease wages only marginally, but they significantly reduce capital. Consequently, the firms bear the increase in tax burden via lower net profits. Despite the different reaction on the employers' side, the model predicts very similar decline of output. The decline in net profit is more pronounced in the case of tax rate increase.

\subsection{Consolidation strategies on the side of revenues versus expenditures}


Moving from consolidation strategies at the revenue side to those on the expenditure side, a scenario reducing family related transfers and credits and a scenario reducing material need benefits is analysed. These expenditures cutting scenarios are described in detail in Table 3 bellow. The first scenario has much larger effect compared to the latter one. Fiscal effect stems from the decline in social transfers, and on top of that, in the former scenario, from abolishing the tax credit for dependent children for high income individuals. In both scenarios, households face decline in their disposable income, which translates into a decline in the government revenue from value added tax.

Table 3: Description of benchmark scenarios (continued)

\begin{tabular}{|c|c|c|}
\hline Scenario name & Actual/baseline legislation & Simulated policy change in scenario \\
\hline \multicolumn{3}{|c|}{ Cutting expenditures } \\
\hline \multirow[t]{3}{*}{$\begin{array}{l}\text { Reduction of } \\
\text { family related } \\
\text { transfers and } \\
\text { credits }\end{array}$} & $\begin{array}{l}\text { Family transfers include: } \\
\text { - parental allowance (monthly } 214.70 \\
€ \text { ) } \\
\text { - child benefits (monthly } 23.69 € \text { and } \\
\quad 11.1 € \text { per child) } \\
\text { - child birth benefit (one-time } 829.86 € \\
\text { at birth) }\end{array}$ & $\begin{array}{l}\text { The eligibility for family transfers is } \\
\text { tested against an assessed income } \\
\text { defined as the gross taxable income of } \\
\text { members of the family. If the family's } \\
\text { assessed income is higher than } 4 \text { times } \\
\text { the amount of their minimum } \\
\text { subsistence level (MSL), the family } \\
\text { transfers are not granted. }\end{array}$ \\
\hline & $\begin{array}{l}\text { Entitlement to family transfers is } \\
\text { currently unconditional on income and } \\
\text { applies up to } 3 \text { years of age of the child. } \\
\text { Child birth benefit is granted up to the } \\
\text { third childbirth. }\end{array}$ & $\begin{array}{l}\text { Tax credit for dependent children is } \\
\text { not granted if the above-mentioned } \\
\text { income condition is fulfilled. }\end{array}$ \\
\hline & $\begin{array}{l}\text { Tax credit for dependent children in the } \\
\text { amount of } 21.41 € \text { monthly per child. }\end{array}$ & \\
\hline \multirow[t]{2}{*}{$\begin{array}{l}\text { Reduction of } \\
\text { material need } \\
\text { benefits }\end{array}$} & $\begin{array}{l}\text { Material need allowances consist of: } \\
\text { - basic material need benefit }(\mathrm{MNB}) \\
\text { varies from } 61.60 € \text { up to } 216.10 € \\
\text { monthly, depending on the family } \\
\text { structure. } \\
\text { - allowance for pregnant women and } \\
\text { parent of children up to } 1 \text { year of age: } \\
13.50 € \\
\text { - activation and protection allowance: } \\
\quad 63.07 € \\
\text { - housing allowance: } 55.80 € \text { or } 89.20 \\
€, \text { depending on the family structure }\end{array}$ & $\begin{array}{l}\text { Reduction of MNB (of all allowances) } \\
\text { by } 10 \% \text {. }\end{array}$ \\
\hline & $\begin{array}{l}\text { Family is eligible for MNB if their } \\
\text { assessed income (net income from } \\
\text { labour plus pensions) is below MSL of } \\
\text { the family. MSL levels are: } \\
\text { - first adult } 199.48 € \\
\text { - jointly considered another person } \\
\quad 139.16 €\end{array}$ & \\
\hline
\end{tabular}


The two scenarios differ considerably with respect to the behavioural reaction of labour supply. In the scenario when the transfers are withdrawn from high earners, the labour supply hardly reacts. Therefore, also the long-run effects are negligible.

On the contrary, the reduction of material need benefits affects those with the lowest income, thus invoking significant labour supply reaction as they have higher labour supply elasticities. In the long-run, following high labour supply response, the employment rises and firms react by decreasing wages. This results into the decrease of unit labour costs. Consequently, the output of the economy and profit of the firms rises. The government revenues from corporate income tax rises as well. A note on the interpretation of this result need to be made at this point. A significant reaction of the extensive margin followed by an employment rise should be considered as an upper bound of the effect. We argue that the decision of the inactive individuals to enter the labour market is not always driven only by financial motivation, modelled in our framework, but also by other factors that are not captured in our model. Therefore, in reality, it can be expected that the reaction would be lower. To sum up, in opposition to the strategies on the revenue side, the analysed spending cuts strategies are not detrimental or even promote the longrun economic growth. This result is in line with literature findings, see the summary assessment of growth effects of fiscal consolidation instruments reported by Cournede et al., 2013 (in Table 2).

\section{CONCLUSION}

The fiscal challenges, that many advanced economies face, require adjusting a broad range of tax and spending cuts instruments. The question of their appropriate mix is still open and the practise varies across countries. In other words, there is a growing consensus in the literature that no one-size-fits-all approach exists (Cournede et al, 2013) and that economic and social situation of countries should be considered by adjusting the usage of consolidation objectives. When tax and spending cuts policies are designed, the impact of fiscal adjustments on the aggregate macroeconomic performance is of great relevance, as well as a balance between distributional and efficiency objectives.

This analysis provides an evaluation of the effect of selected benchmark consolidation measures on fiscal stance, economic growth and income inequality in Slovakia. Our approach combines the microsimulation analysis that allows to evaluate the impact of the individual policy instruments 
separately and their incidence along the households' income distribution, to simulate the behavioural reaction on the labour market and finally to provide an assessment of the long-run general equilibrium effects. We find a considerable variation in terms of magnitude and implied effects of the tested instruments. The amount of the deficit reduction naturally varies depending on instruments chosen. Our empirical results confirm that taxing labour and consumption has both a negative effect on individuals' motivation to work, but in the long-run increasing labour taxes is more detrimental to employment and output growth than taxing consumption. We analyse the distribution of the tax burden between employers and employees when the consolidation is driven by an increase in employers' and employees' health insurance contributions rates. The empirical evidence confirms that the adjustment process works in the same direction, however, the output declines more in case when the statutory tax incidence is levied on employees. On the other hand, the two spending cuts strategies that we analyse are not detrimental to output growth. Cuts of transfers to households enforce positive reaction of the labour supply and in the long-run employment grows.

We consider presented empirical results as a starting point that may serve for further analysis. Our methodology can be used as a tool that can practically examine different tax and transfer system reform packages that are currently discussed in Slovakia - in terms of their efficiency and political workability. In addition, important topic might be to test such reform packages that are revenue neutral, but not detrimental to income inequality.

Finally, it should be pointed out that we have not considered the consequences of the measures from the perspective of the intertemporal consumption decision of households. At the same time, we have assumed - through an appropriate functional form for welfare - that policy decisions have no wealth effect on the labour supply. This allowed us to solve for the labour market dynamics independently of the household's consumption decision. Anticipated changes in the net income may, however, have significant wealth effects. The full implications of these should be taken into account when evaluating the overall effects, including budgetary impacts, of the measures. This is an important extension of our framework which will be addressed in our future work.

\section{REFERENCES}

Alesina A and Ardagna S (2010) 'Large changes in fiscal policy: Taxes versus spending', Tax Policy and the Economy 24, 35-68.

Alesina A and Ardagna S (2013) 'The design of fiscal adjustments', Tax Policy and the Economy 27, $19-67$. 
Anagnostopoulos A, Atesagaoglu O. E. and Carceles-Poveda E (2014) 'On the Double Taxation of Corporate Profits', Department of Economics Working Papers 14-03, Stony Brook University, Department of Economics.

Bakos P, Benczur P, Benedek D (2008) 'The elasticity of taxable income: Estimates and flat tax predictions using the Hungarian tax changes in 2005', National Bank of Hungary Working Paper 2008/7.

Bargain O, Caliendo M, Haan P and Orsini K (2005) 'Making work pay in a rationed labour market - the mini-job reform in Germany', DIW Discussion Paper 536, Berlin.

Benčík M (2008) 'Methods for Detecting Disequilibrium in the real Economy of Slovak Republic' NBS Working Paper 2008/2, National Bank of Slovakia.

Cockburn J, Savard L and Tiberti J (2014) 'Macro-Micro Models', in Cathal O’Donoghue (ed.), Handbook of Microsimulation Modelling, Contributions to Economic Analysis, vol. 293, 275-304, Emerald Group Publishing Limited.

Cournede B, Goujard A and Pina A (2013) 'How to Achieve Growth- and Equity-friendly Fiscal Consolidation? A Proposed Methodology for Instrument Choice with an Illustrative Application to OECD Countries', OECD Economics Department Working Papers, No. 1088, OECD Publishing.

Decoster A, Ochmann R and Spiritus K (2014) 'Integrating VAT into EUROMOD. Documentation and results for Belgium', EUROMOD Working Paper EM 12/14. Essex: EUROMOD at the Institute for Social and Economic Research

European Commision (2013) 'Labour market developments in Europe', 2013. European Economy 6/2013.

European Commission (2015a) 'Study on the effects and incidence of labour taxation', Taxation Paper No 56

European Commission (2015b) 'Tax Shifts', Taxation Paper No 59

Farmer R E A (2013) 'Animal Spirits, Financial Crises and Persistent Unemployment', The Economic Journal, 123 (May), 317-340.

Farmer R E A (2014) 'The Evolution of Endogenous Business Cycles, Macroeconomic 
Dynamics', available on CJO2014. doi:10.1017/S1365100514000248.

Fesseau M, Wolff F and Mattonetti M-L (2013) 'A cross-country comparison of household income, consumption and wealth between micro sources and national accounts aggregates', OECD Statistics Working Papers, No. 2013/04, OECD Publishing

Figari F, Paulus A and Sutherland H (2015) 'The design of fiscal consolidation measures in the European Union: distributional effects and implications for macroeconomic recovery', EUROMOD Working Papers EM5/15, EUROMOD at the Institute for Social and Economic Research.

Gruber J, Saez E (2002) 'The elasticity of taxable income: evidence and implications', Journal of Public Economics, 84, 1-32.

Hausman JA (1981) Labor Supply. How Taxes Affect Economic Behavior, in H. Aaron and J.Pechman (eds.), The Brookings Institution, Washington D.C., 27-72.

Heathcote J and Tsujiyama H (2015) 'Optimal Income Taxation: Mirrlees Meets Ramsey', Federal Reserve Bank of Minneapolis, Research Department Staff Report 507.

Horvath M, Senaj M, Siebertova Z and Svarda N (2015) 'The End of the Flat Tax Experiment in Slovakia', CBR Working paper 4/2015, Council for Budget Responsibility.

IMF (2010) 'Will it hurt? Macroeconomic effects of fiscal consolidation', In World Economic Outlook, Chapter 3, 93-124.

Kiss A and Mosberger P (2015) 'The elasticity of taxable income of high earners: evidence from Hungary', Empirical Economics, 48 (2), 883-908.

Nemec D (2013) 'Investigating Differences Between the Czech and Slovak Labour Market Using a Small DSGE Model with Search and Matching Frictions', Czech Economic Review 7, 21-41.

OECD/Korea Institute of Public Finance (2014) 'The Distributional Effects of Consumption Taxes in OECD Countries', OECD Tax Policy Studies No. 22, OECD Publishing

Pestel N and Sommer E (2017) 'Shifting taxes from labor to consumption: More employment and more inequality', Review of Income and Wealth, 63(3), 524-563.

Pissarides Ch A (2000) 'Equilibrium unemployment theory' - 2nd ed. The MIT Press. 
Senaj M, Siebertova Z, Svarda N and Valachyova J (2016) 'Labour force participation elasticities and the move away from a flat-tax: the case of Slovakia', IZA Journal of European Labor Studies, 5-19.

Siebertova Z, Svarda N and Valachyova J (2016) 'Improving the Validity of Microsimulation Results: Lessons from Slovakia', International Journal of Microsimulation, 9(2), 77-105.

Siebertova Z, Valachyova J, Svarda N and Senaj M (2018) 'Expenditure imputation and microsimulation of VAT', CBR Discussion paper 1/2018, Council for Budget Responsibility.

Zeleznik M (2012): 'Labour Market in Central European Countries: Small Search and Matching DSGE Model', Biatec, 20 (10), 12-16.

ZEW (2012): 'Effective Tax Levels Using the Devereux/Griffith Methodology'. Project for the EU Commision. 


\section{APPENDIX}

\section{A MODEL FRAMEWORK: DETAILS}

\section{A.1 Slovak tax and transfer system}

The system is largely unified and its components are set mainly at the state level. Individuals are subject to the personal income tax (PIT) and the joint taxation of married couples is not permitted. PIT is levied on gross income including wages from employment, self-employment income, fringe benefits, capital, rental and interest income. Social and health insurance contributions (SIC) are exempt from the tax base which is given as gross earnings net of paid SIC. Deductions from the tax base include basic tax allowance, spouse tax allowance and child tax credit. Every individual is entitled to the basic tax allowance that is defined based on minimum subsistence level. A progressive reduction in its amount applies when earnings exceed the threshold value. If earnings of a spouse are under certain level, the tax payer can apply for a spouse tax allowance. In addition, one spouse may claim child tax credit, an allowance for every child in the household. Income tax is calculated by applying the appropriate tax rate schedule to tax base. Basic tax rate is set to 19 per cent and 25 per cent rate is applied to incomes exceeding the threshold. However, this threshold is sufficiently high, so the higher tax rate relates in our estimation sample to less than 1 per cent of employees.

The SIC payments are split between employer and employee. The assessment base for contributions differs from the base for computation of PIT and has a maximum. Payments by employers and employees consist of health, unemployment, sickness, disability, and old age insurance, but the two categories pay different percentages from the assessment base. Besides this, employers pay contributions to a reserve solidarity fund, accident insurance and guarantee insurance.

The Slovak benefit system consists of contributory benefits, social assistance and state social support. Each component consists of several programs.

a) Contributory benefits cover various pensions (old-age, disability, widower's, orphans), sickness benefit, maternity benefit and unemployment insurance benefit.

b) Social assistance program includes material needs benefit which is a means-tested transfer provided to families to provide them basic living standard if their income is below the minimum subsistence level.

c) The state social support program includes several family related benefits (e.g. child birth grant, child benefit, or parental allowance). Eligibility to these transfers does not depend on the contribution history and is not means-tested. 


\section{A.2 The labour supply model}

We have adopted the microeconometric approach to model the labour supply behaviour such that two components are considered - the decision whether to actively participate in the labour market (extensive margin) and the decision about hours worked conditional on being employed (intensive margin).

We model individual participation decision about supplying labour following the methodology proposed by Benczur et al. (2014). Their extension of the standard labour supply model built on the rationale of utility maximization (Hausman, 1981) allows to consider taxes and social transfers simultaneously. When using the categorization of labour supply models within microsimulation framework provided by Aaberge and Colombino (2014), it can be classified as a "marginalist" approach. Using this static setting, the savings behaviour is not modelled. The applied set up leads to a re-definition of the reservation wage (the threshold to accept a wage offer) at the cost that the participation decision is constrained to a full-time job. However, we argue that this assumption is in the context of Slovakia not a substantial restriction. As shown by EUROSTAT, Slovakia is the country with one of the lowest rates of part-time employment. In 2016 the share of part-time workers reached only 5.7 percent as opposed to 19 percent in the EU-28.

The individual takes the participation decision, or in other words becomes economically active, if the utility from working full-time exceeds the utility derived from being inactive (and receiving full amount of social transfers). Taking into account the corresponding budget constraints and assuming the additively separable utility function and the normality of error terms, the probability that an individual is economically active can be estimated by a probit equation (for the details of derivation, see Senaj et al., 2016):

$$
\operatorname{Pr}\left(\text { activity }_{i}=1\right)=\Phi\left(\gamma \log G T W_{i}+Z_{i}^{\prime} \alpha-\psi \log N Y_{i}\right) .
$$

Variables $G T W_{i}$ and $N Y_{i}$ are of principal interest and for their construction a microsimulation tool is needed. $G T W_{i}$ denotes the gains to work (or effective net wage) of the individual $i$, defined as the net wage $\widehat{w}_{l}$ minus the difference between social benefits received if not working and social benefits if working:

$$
G T W_{i}=\widehat{W_{l}}-\left(S B^{N W}-S B^{W}\right)=\widehat{W_{l}}-\Delta S B .
$$

Since income from employment is obviously unobservable for those who are unemployed or inactive, in the first step Heckman's sample selection methodology is applied to predict individual's gross wages. In the next step, the SIMTASK tax and benefit calculator is used to compute net wages from gross wages and to simulate the amount of social benefits an individual is entitled to when working $\left(S B^{W}\right)$ and when not working $\left(S B^{N W}\right)$, considering simultaneously the individual's characteristics as well as the characteristics of the household an individual belongs 
to. Using the details of the Slovak tax and transfer system, social benefits that are included in the variable GTW are the means-tested material needs benefit and its supplements allocated at the household level.

The non-labour income $N Y_{i}$ of the individual $i$ sums three components, in particular the social transfers that one receives when not working, the non-labour income of all household members (including individual $i$ ) and the net labour income of other household members. Non-labour income includes pensions, income from property, dividend payments, and family-related benefits (these are not means-tested and their eligibility does not depend on whether a parent works or not) and the unemployment benefit (a contributory benefit that expires after six months, so we assume that this transfer does not affect the decision to work). Finally, the vector $Z_{i}$ comprises a set of observable individual socio-demographic characteristics.

Both variables $G T W_{i}$ and $N Y_{i}$ after their values are simulated are divided by the households' effective value-added tax rate $e V A T$. This adjustment $\frac{G T W_{i}}{1+e V A T}$ and $\frac{N Y_{i}}{1+e V A T}$ is technically a rescaling of the two variables that affects the real disposable income of an individual, but it does not affect the decision to work. The effective VAT rate is defined as the share of revenues from VAT paid to total households' expenditures. To simulate VAT, in the first step we create a combined dataset that integrates the information on households' expenditures from the Slovak Household Budget Survey (HBS) and the disposable income covered in SILC database. We apply a parametric imputation technique using the methodology developed by Decoster et al. (2014). Engel curves relating consumption expenditures to disposable income are estimated at the household level using the data from HBS 2015. Coefficient estimates are then used to impute the information on consumption to the underlying SILC dataset. In the next step, VAT liabilities are simulated using the imputed household consumption. For details, the interested reader is referred to our discussion paper by Siebertova et al. (2018).

Equipped with the vectors gains to work and non-labour income, the probit model of participation decision is estimated separately for males and females on the pooled sample of SILC data from 2012-15 (Table A.1). The estimated results are statistically significant and have the expected sign. An increase in gains to work increases the individuals' probability of participation, on the other hand an increase in non-labour income decreases motivation to be economically active. 
Table A.1: Point estimates of probit model (pooled regression 2012-15)

\begin{tabular}{|c|c|c|c|c|c|}
\hline \multirow{2}{*}{$\begin{array}{l}\text { Dependent variable ACTIVE } \\
\log \text { GTW }\end{array}$} & \multicolumn{2}{|c|}{ Females } & \multicolumn{3}{|c|}{ Males } \\
\hline & 0.314 & $* * * \quad(0.043)$ & 0.248 & $* * *$ & $(0.054)$ \\
\hline $\log \mathrm{NY}$ & -0.201 & *** $\quad(0.018)$ & -0.181 & $* * *$ & $(0.023)$ \\
\hline EDU: Secondary & 0.586 & *** $(0.033)$ & 0.626 & $* * *$ & $(0.039)$ \\
\hline EDU: Tertiary & 0.760 & *** $(0.042)$ & 0.843 & $* * *$ & $(0.051)$ \\
\hline Parent with child under $3 y$. & -2.159 & $* * * \quad(0.037)$ & 0.450 & $* * *$ & $(0.087)$ \\
\hline Parent with child over $3 y$. & 0.075 & ** $\quad(0.029)$ & 0.413 & $* * *$ & $(0.044)$ \\
\hline Fam: Married & -0.070 & $*(0.036)$ & -0.076 & $*$ & $(0.045)$ \\
\hline Fam: Divorced / Widowed & 0.121 & $* * * \quad(0.040)$ & -0.002 & & $(0.066)$ \\
\hline Has working partner & 0.229 & $* * * \quad(0.034)$ & 0.289 & $* * *$ & $(0.042)$ \\
\hline Chronic disease & -0.728 & *** $\quad(0.025)$ & -1.162 & $* * *$ & $(0.032)$ \\
\hline Student & -2.042 & *** $(0.038)$ & -2.240 & $* * *$ & $(0.040)$ \\
\hline Pensioner & -2.465 & $* * * \quad(0.034)$ & -2.873 & $* * *$ & $(0.047)$ \\
\hline Year 2013 & -0.072 & $* * \quad(0.030)$ & 0.054 & & $(0.038)$ \\
\hline Year 2014 & -0.103 & *** $\quad(0.030)$ & 0.051 & & $(0.038)$ \\
\hline Year 2015 & -0.107 & *** $(0.030)$ & 0.036 & & $(0.038)$ \\
\hline Constant & 0.090 & $(0.367)$ & 0.580 & & $(0.479)$ \\
\hline Observations & 27682 & & 24057 & & \\
\hline R2 pseudo & 0.538 & & 0.638 & & \\
\hline
\end{tabular}

Notes: Standard errors in parentheses, ${ }^{* * *} \mathrm{p}<0.01$, ${ }^{*} \mathrm{p}<0.05,{ }^{*} \mathrm{p}<0.1$. Reference categories for the dummies: Education (ref. Elementary) Family status (ref. Single), Year (ref. 2012).

Estimated coefficients of the probit model directly enter to the assessment of the participation effect of the consolidation strategies. The gains to work and non-labour income are simulated for every individual in baseline and consolidation scenario. In addition, coefficient estimates of Engel curves are used to calculate households' consumption both in baseline and scenario and the effective VAT rate is simulated for every household. The adjusted gains to work and non-labour income are used to evaluate individual participation probabilities $\widehat{p}_{\imath}=\Phi\left(\hat{\gamma} \log W_{i}+Z_{i}^{\prime} \hat{\alpha}-\right.$ $\left.\hat{\psi} \log N Y_{i}\right)$ both in baseline and scenario cases.

The second labour supply decision refers to the number of hours worked, conditional on working. For this intensive margin response, the baseline and scenario changes in the effective average $(A E T R)$ and marginal (METR) tax rates need to be evaluated. Using a variant of Gruber and Saez (2002) original approach, Bakos et al. (2008) derived the relationship between income growth $\widehat{w}$ and tax rates

$$
\Delta \ln (\widehat{w})=\varepsilon_{m} \Delta \ln (1-M E T R)+\varepsilon_{a} \Delta \ln (1-A E T R) .
$$

The parameter $\varepsilon_{m}$ is the effective marginal net-of-tax rate elasticity (substitution effect) and $\varepsilon_{a}$ represents the effective average net-of-tax rate elasticity (income effect). Since appropriate data to 
estimate these elasticities is not available, we use calibrated values. Following Kiss and Mosberger (2015) estimation for Hungary, $\varepsilon_{m}$ is set to 0.2 for the top 20 percent of the income distribution and $\varepsilon_{a}$ is set to zero. In our implementation, hours worked in baseline is set to 1 . The response of an individual at the intensive margin is the relative change in the effective hours worked. After some manipulations it can be expressed as a function of the marginal and the average effective tax rates and income growth:

$$
\widehat{\mathrm{h}}=\frac{h_{S c}}{h_{b a}}=1+\xi\left\{e^{\left[\varepsilon_{m} \Delta \ln (1-M E T R)+\varepsilon_{a} \Delta \ln (1-A E T R)+\left(\varepsilon_{m}+\varepsilon_{a}\right) \widehat{w}\right]}-1\right\}
$$

where $\xi$ stands for the correction term function that is assumed to be close to one $(\xi \approx 1)$.

To complete the micro part, a note on the model of employment is discussed. We model the employment such that the labour supply model of individual participation decision is combined with a rationing risk model (Bargain et al., 2005). In the standard labour supply models, it is assumed that individuals can find an employment with certainty. If this assumption is relaxed, there exist individuals who want to work but do not find an employment, thus they are involuntary unemployed. The risk of rationing - an individual probability of being involuntary unemployed - can be estimated as a probit specification

$$
\operatorname{Pr}\left(\operatorname{IUNEMP}_{i}=1\right)=\Phi^{R}\left(X_{i}^{\prime} \beta\right) .
$$

IUNEMP is a binary variable that equals one if an individual is involuntary unemployed and zero otherwise, $\mathrm{X}$ contains individual and local labour market characteristics (demand side variables) that influence the probability of rationing. In our representation, individual characteristics include education, age and labour market experience in the quadratic form, dummies for no work history and unfavourable health status. Controls for local labour market characteristics include dummy for the density of settlement and regional unemployment rate. Detailed specification and estimation results are available upon request.

If it is assumed that there exist individuals who are involuntarily unemployed, the decision process of an individual can be described as a double-hurdle. First, decision whether to participate in the labour market or to stay inactive should be taken. Second hurdle concerns the probability of being involuntarily unemployed if the person is active. Therefore, individual can be found in one of the following 3 states: being inactive, being active and involuntarily unemployed and finally, active and working full-time. Under the assumption that the two processes are independent, the probit equations can be estimated separately. The probability of being employed considered in the second hurdle is estimated such that probabilities of the standard model are multiplied by the probabilities implied by the rationing risk model: 


$$
\operatorname{Pr}\left(\operatorname{emp}_{i}=1\right)=\Phi\left(\hat{\gamma} \log G T W_{i}+Z_{i}^{\prime} \hat{\alpha}-\widehat{\psi} \log N Y_{i}\right)\left(1-\Phi^{R}\left(X_{i}^{\prime} \hat{\beta}\right)\right)
$$

Finally, individual employment probabilities in the sample are summed up to get an estimate of the aggregate employment rate.

\section{A.3 The what_if model}

The labour supply model described above allows us to assess the partial equilibrium effects of the proposed policy reform. However, our intention is to evaluate the general equilibrium short- and long-run effects as well. Therefore, we embed our labour supply micro block into a small general equilibrium model. The macroeconomic block defines labour demand and the capital supplydemand equilibrium given a wage level. Another way of looking at our approach is to take Farmer $(2013,2014)$ and think about the behavioural microsimulation exercise as a mechanism performing the task of equilibrium selection.

Our theoretical macroeconomic model is a neo-classical model with simple search and matching frictions, as in Pissarides (2000). The model is consistent with the existence of involuntary unemployment, and so we can calibrate it to match the empirical ratios seen in the micro-data we use, and thus ensure consistency.

We assume that production of goods is given by a standard CES production function which combines effective labour and capital. In the model, it takes time for an unemployed to find a job and also the process of searching for new employees is costly. The representative firm then maximizes its profit:

$$
\max _{K, L, v} E_{t} \sum_{j=t}^{\infty} \beta^{j-t} \lambda_{j}^{c}\left[Y_{j}-\left(1+\tau_{w}\right) w_{j} N_{j}-\frac{r_{j}}{1-\tau_{k}} K_{j}-c v_{j}\right]
$$

Total labour cost per unit of labour is given by $w_{j}\left(1+\tau_{w}\right)$, where $w_{j}$ denote gross wages and $\tau_{w}$ is the payroll tax paid by employers. The net user cost of capital $K_{j}$ is $r_{j} /\left(1-\tau_{k}\right)$, where $r_{j}$ is the price of capital, and $\tau_{k}$ denotes the effective corporate tax rate. Hiring costs are given by the expression $c v_{j}$, where $v_{j}$ is the vacancy rate and $c$ is the corresponding cost parameter.

The optimization process is constrained by the following three conditions:

1. Production function in standard CES form combines capital and effective labour:

$$
Y_{j}=\left[\alpha K_{j}^{\sigma}+(1-\alpha) L_{j}^{\sigma}\right]^{\frac{1}{\sigma}}
$$

2. Growth of employment. The variable $q$ is the probability of filling a vacancy: 


$$
N_{j}=(1-\lambda) N_{j-1}+v_{j} q
$$

3. The relationship between effective labour and employment:

$$
L_{j}=\chi N_{j}
$$

In what follows, we set out the relationships characterizing the long-run steady state of our economy which together give us the set of equations channeling the labour supply shock coming from the microsimulation exercise.

The optimality conditions from the firms' problem link the price of labour and capital to the capital and labour. In the steady state we have:

$$
\begin{gathered}
(1-\alpha) L^{(\sigma-1)}\left(\alpha K^{\sigma}+(1-\alpha) L^{\sigma}\right)^{\left(\frac{1}{\sigma}-1\right)}=\frac{\left(1+\tau_{w}\right) w}{\chi}+\frac{c}{\chi q}\left(1-(1-\lambda) \beta \lambda^{c}\right) \\
\alpha K^{(\sigma-1)}\left(\alpha K^{\sigma}+(1-\alpha) L^{\sigma}\right)^{\left(\frac{1}{\sigma}-1\right)}=\frac{r}{1-\tau_{k}}
\end{gathered}
$$

The Slovak economy is a very open one with much of private investment taking the form of foreign direct investment. This, we believe, allows us to assume perfect capital mobility.

We use a standard Cobb-Douglas matching function:

$$
m=\mu u^{\xi} v^{(1-\xi)}
$$

where, $\mu$ and $\xi$ are parameters. Employment $N$ in this economy at any point in time equals past employment less separations plus new hires. In the steady state, this implies the following expression where $\lambda$ is the separation rate.

$$
N=\frac{v q}{\lambda}
$$

Steady-state unemployment rate is given simply as follows:

$$
u=1-N
$$

Finally, the probability of filling a vacancy and the probability of being matched with a job are defined as follows

$$
\begin{aligned}
& q=\frac{m}{v} \\
& p=\frac{m}{u}
\end{aligned}
$$

The steady state equations (11) - (17) form the macroeconomic block of the model used for simulation of long run effects. Parameter values are summarized in Table A.2. 
Table A.2: Summary of the parameters used in the macro block of the model

\begin{tabular}{crl}
\hline Parameter & \multicolumn{1}{c}{ Value } & Description / Source \\
$\alpha$ & 0.43 & $\begin{array}{l}\text { Share of labour in CES production function estimate } \\
\text { (Bencik, 2008) }\end{array}$ \\
$\sigma$ & $0.99-1) / 0.48$ & $\begin{array}{l}\text { Transformed elasticity of substitution (Bencik, 2008) } \\
\beta\end{array}$ \\
$\lambda$ & $0.004 \begin{array}{l}\text { Discount factor } \\
\text { Job separation rate } \\
\text { (Labour Market Developments in Europe 2013, EC, 2013) }\end{array}$ \\
$\xi$ & $0.8 \begin{array}{l}\text { Match elasticity of the unemployed } \\
\text { (Zeleznik, 2012 or Nemec, 2013) }\end{array}$ \\
$\mu$ & $0.05 \begin{array}{l}\text { Scaling factor of matching function - efficiency of the process } \\
\text { (calibrated) }\end{array}$ \\
$c$ & $1.00 \begin{array}{l}\text { Vacancy posting costs (calibrated) } \\
\text { Quarterly interest rate - price of capital (calibrated) }\end{array}$ \\
$\tau_{K}$ & 0.01 & $\begin{array}{l}\text { Quate } \\
\text { Effective corporate income tax rate (calibrated) }\end{array}$ \\
\hline
\end{tabular}

\section{A.4 Linking micro and macro block of the model}

To link the two parts of the model, the micro and macro part, we employ a version of an iterative procedure known in the literature as a top-down/bottom-up approach. In the micro (bottom-up part), aggregate labour supply $(L)$, social insurance contributions paid by employers $\left(\tau_{w}\right)$ and effective employment $(N)$ are estimated and serve as an input to macro model:

$$
L=\frac{1}{s} \sum_{i=1}^{s} \frac{\operatorname{Pr}\left(\mathrm{emp}_{i}=1\right) \text { hours }_{i} \operatorname{prod}_{i}}{\frac{1}{S} \sum_{i=1}^{s} \operatorname{Pr}\left(\operatorname{activity}_{i}=1\right)\left[w_{i}\right]}\left[w_{i}\right]
$$

where $\operatorname{Pr}\left(\mathrm{emp}_{i}=1\right)$ and $\operatorname{Pr}\left(\right.$ activity $\left._{i}=1\right)$ denote the probability that an individual $i$ is employed/active, $\operatorname{hours}_{i}$ are hours worked and $\operatorname{prod}_{i}$ measures the individual productivity proxied by the normalized labour income (computed as the share of individual wage to average wage). In other words, we treat the wage distribution as an approximation of the distribution of productivity (see, for example, Heathcote and Tsujiyama, 2015). The number of individuals in the sample is $S$ and $w_{i}$ is the population weight.

$$
\tau_{w}=\frac{1}{s} \sum_{i=1}^{s}\left(\frac{\text { SIC and HIC of employers }}{\text { gross labour income }}\right)_{i}\left[w_{i}\right]
$$




$$
N=\frac{1}{s} \sum_{i=1}^{s} \frac{\operatorname{Pr}\left(\mathrm{emp}_{i}=1\right)}{\frac{1}{S} \sum_{i=1}^{s} \operatorname{Pr}\left(\text { activity }_{i}=1\right)\left[w_{i}\right]}\left[w_{i}\right]
$$

In the macro model, aggregate change in gross wages is computed and serves as an input to micro model (top-down part). This process is repeated until converge is reached, i.e. the change in gross wages computed in macro part is sufficiently small. 


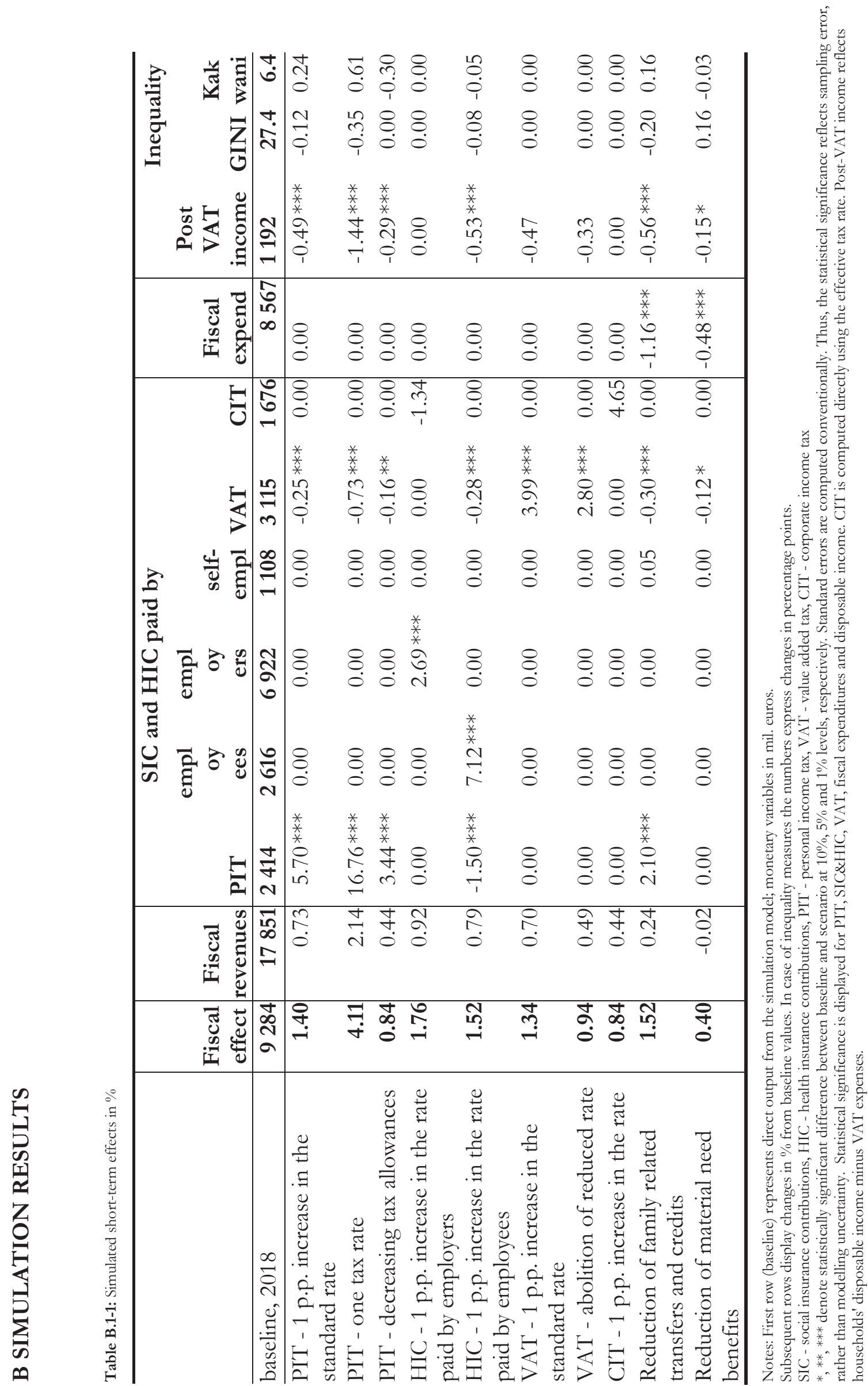




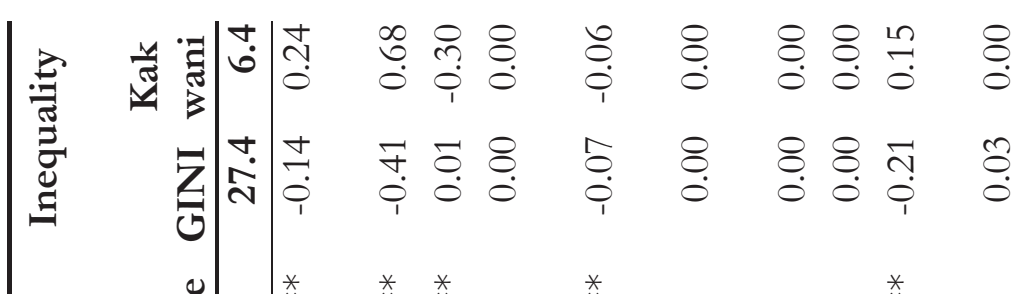

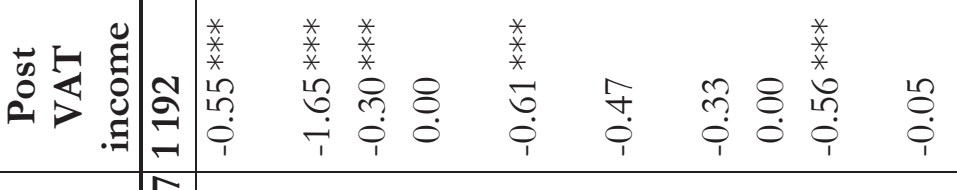

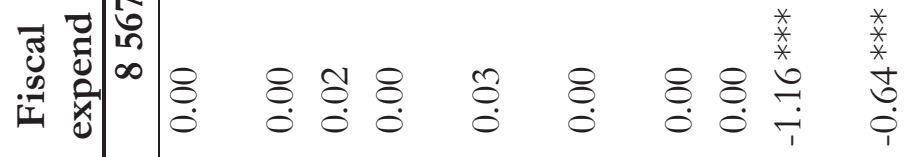
卢苟

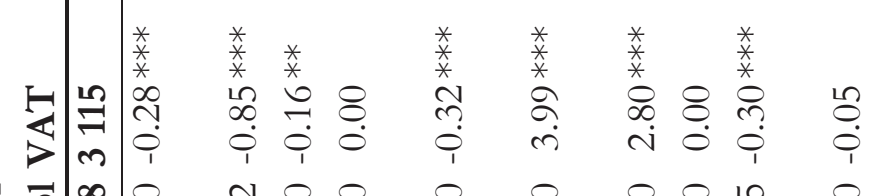

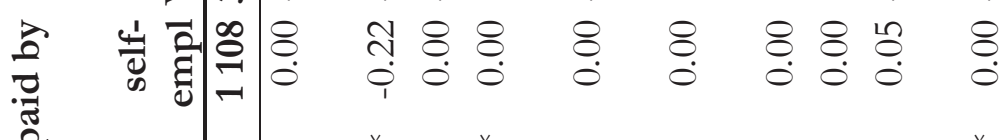

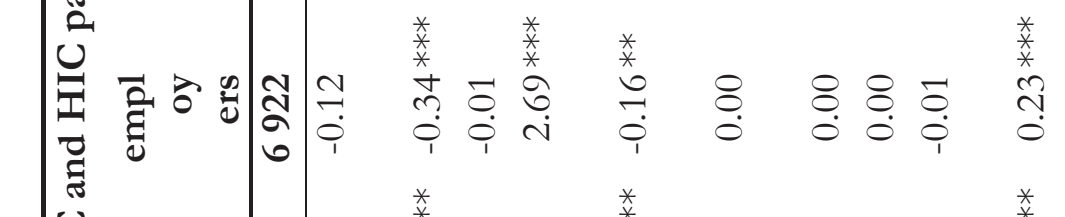

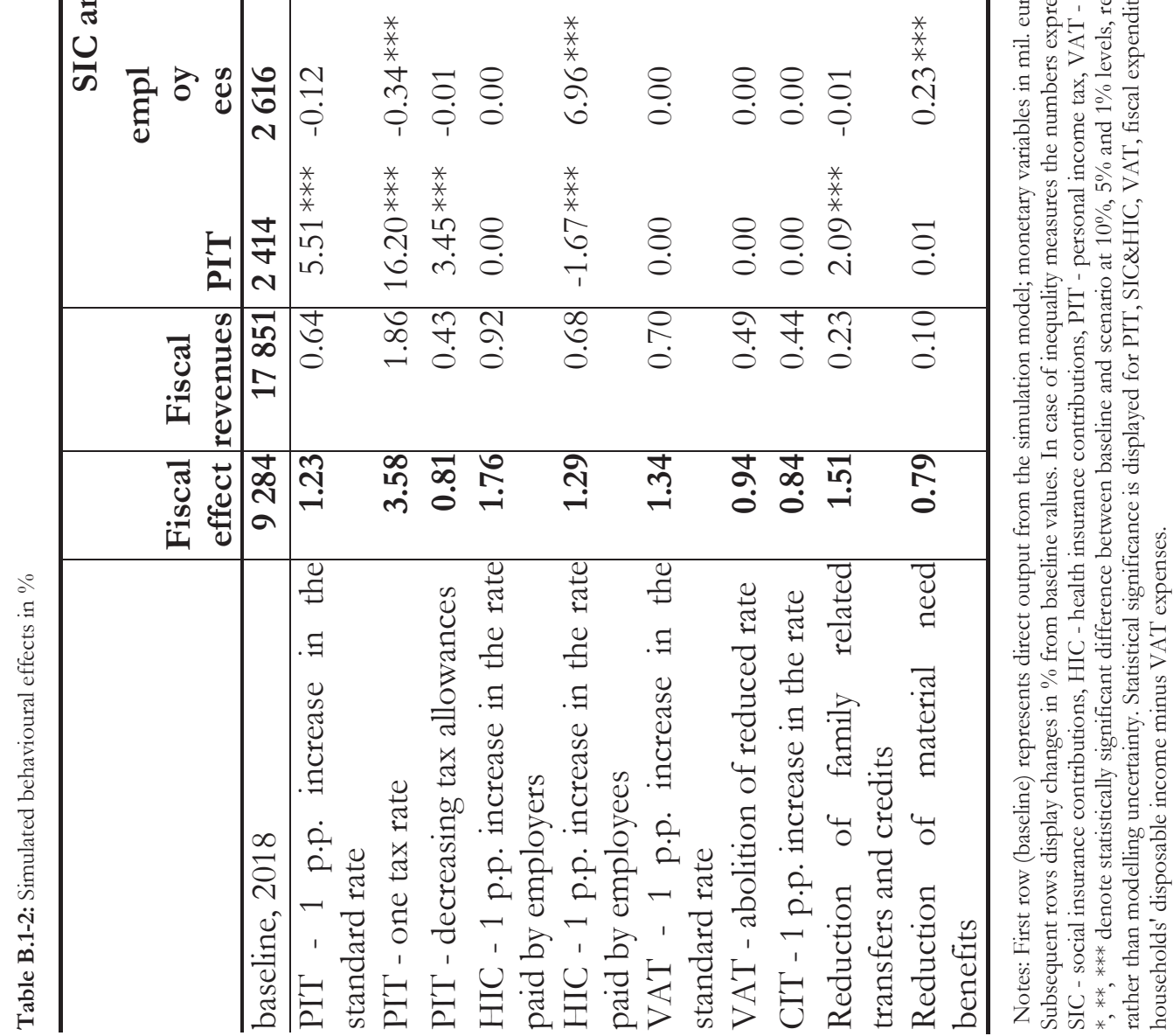




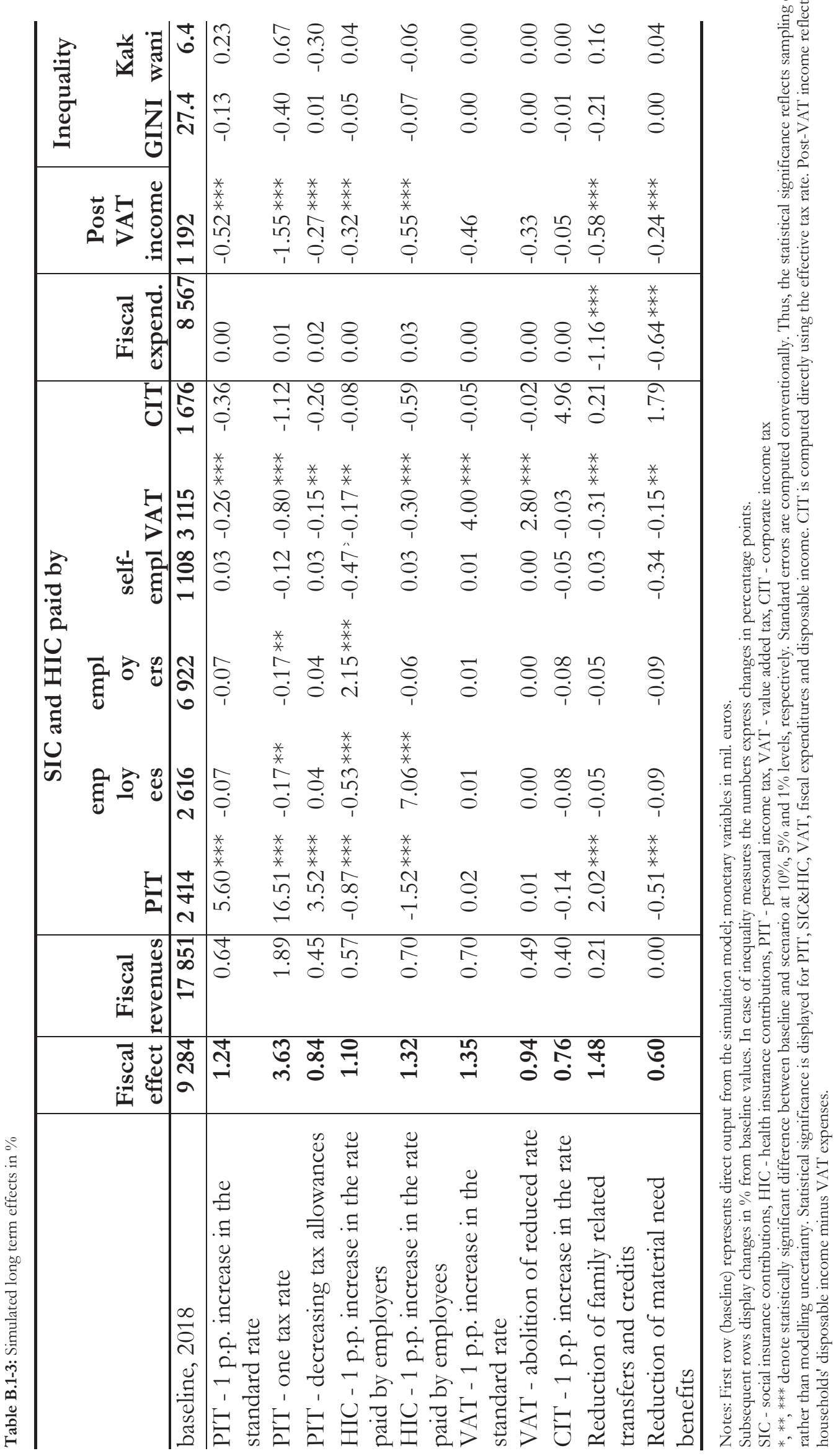




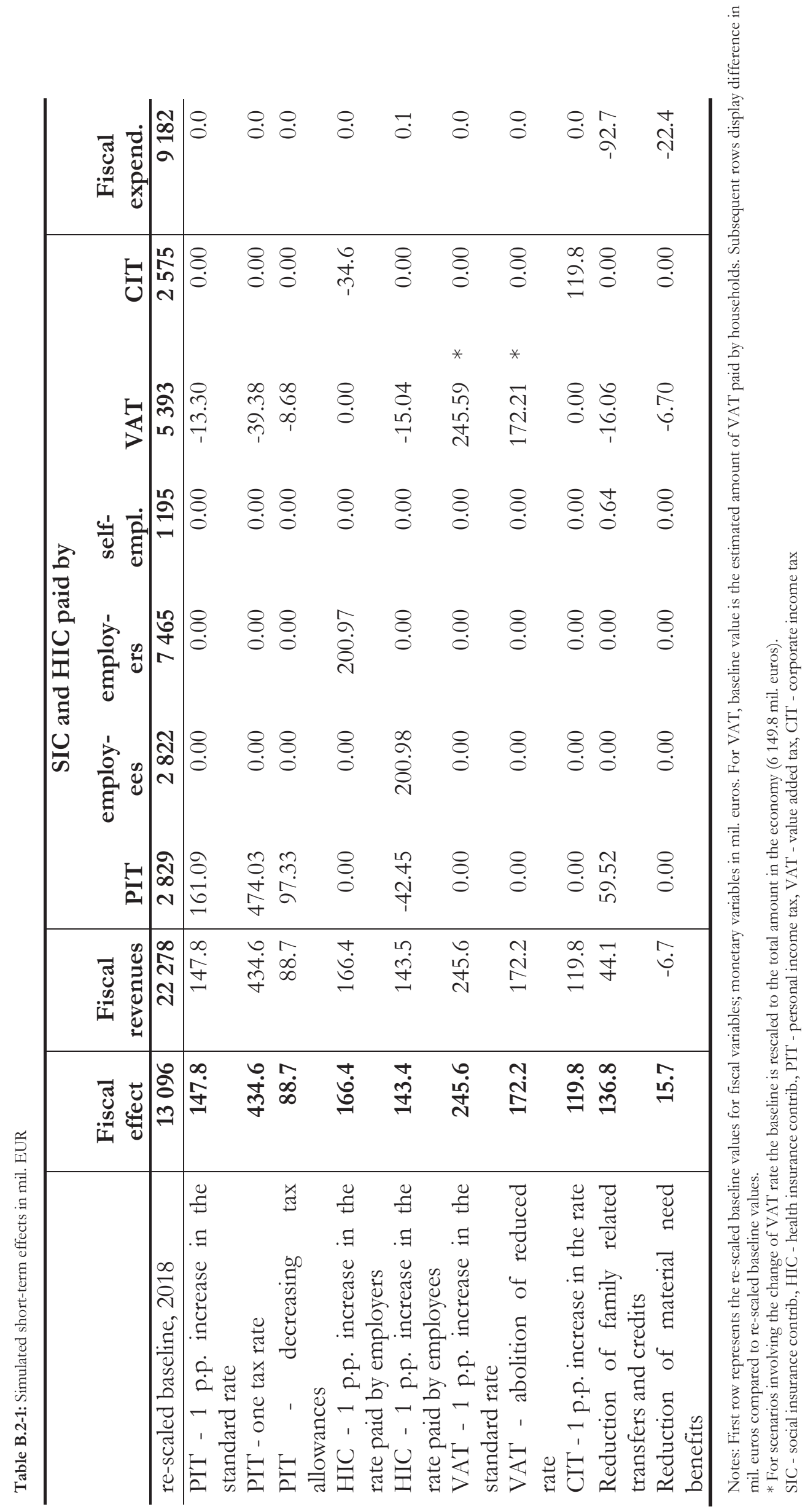




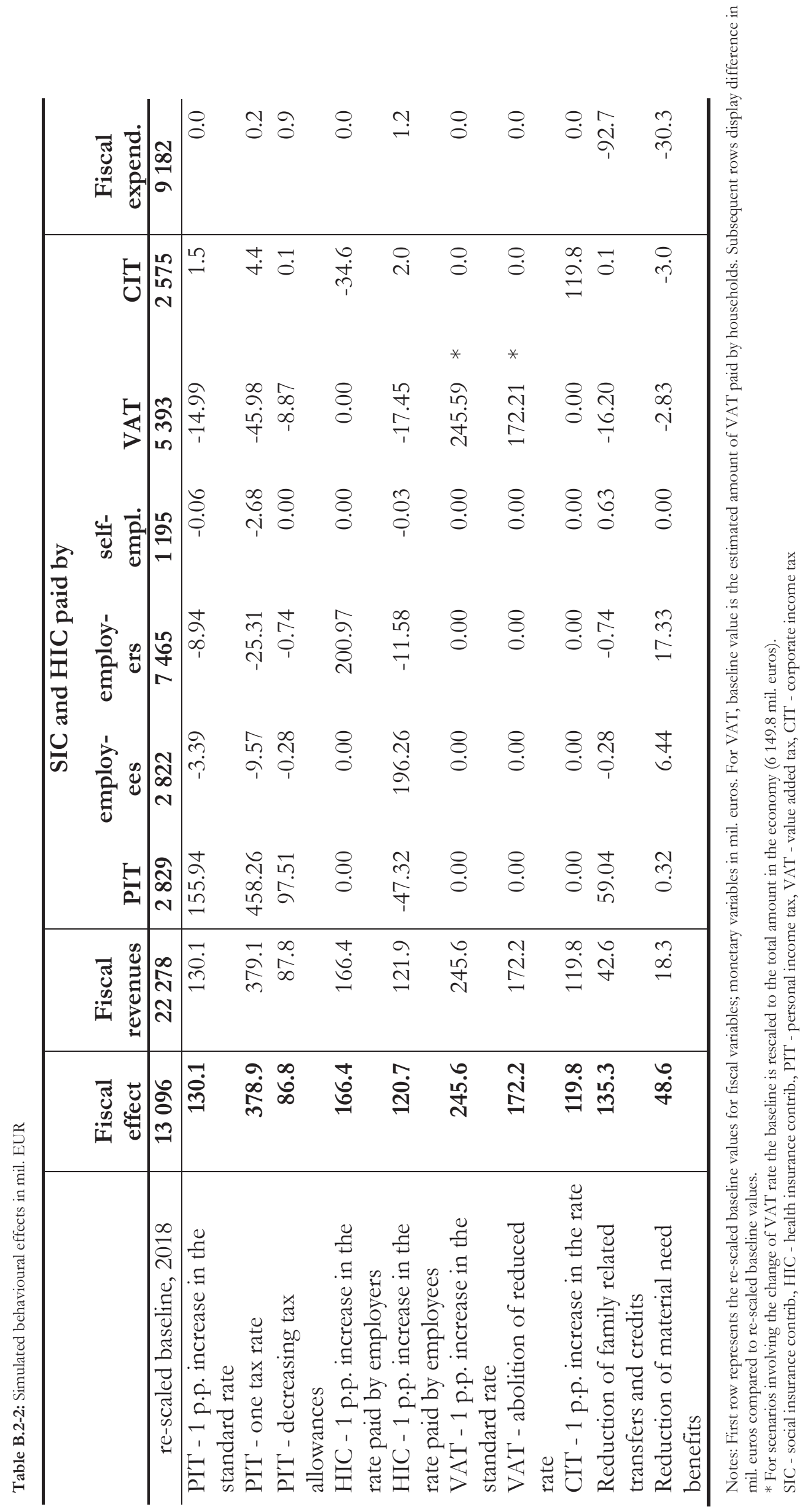




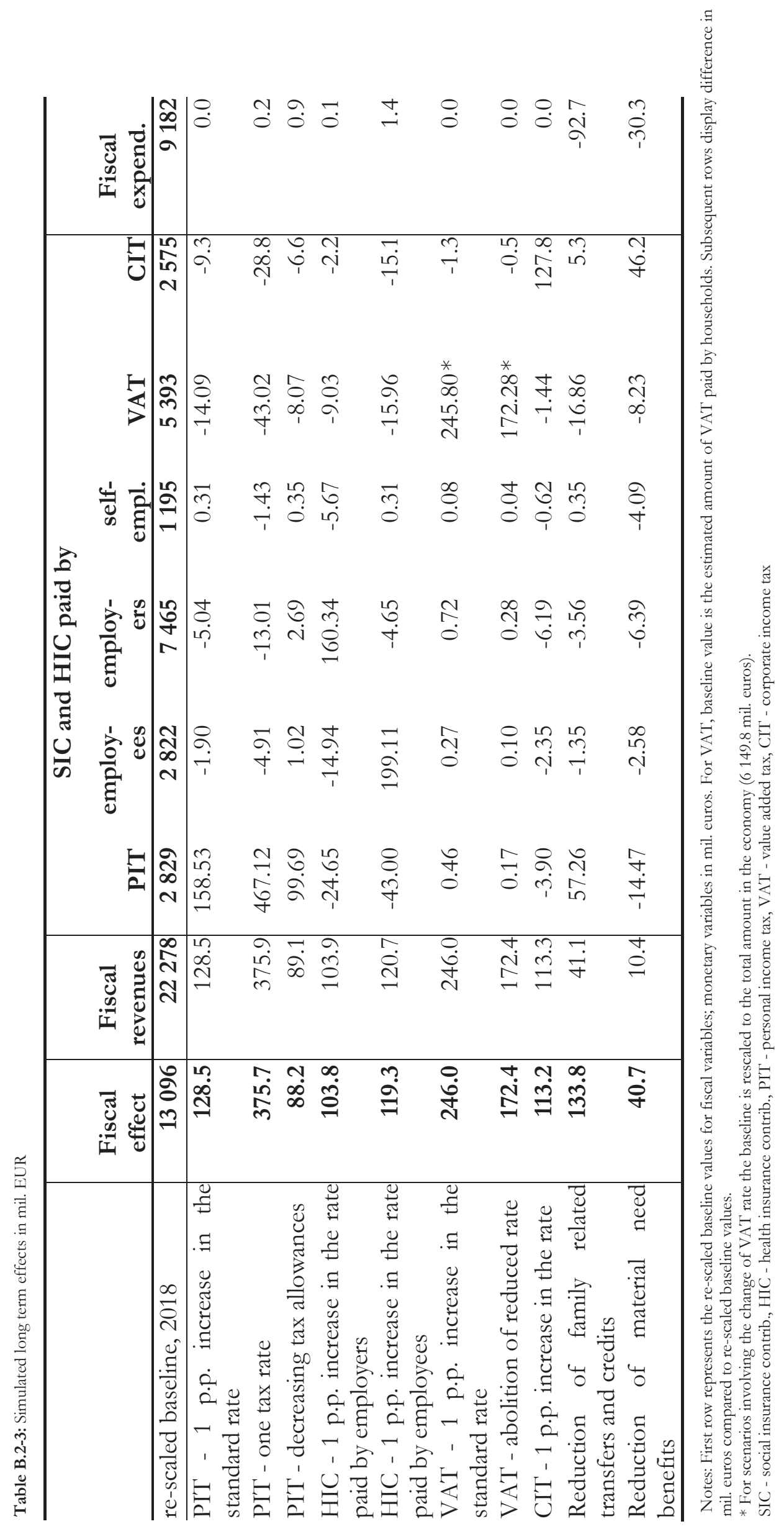




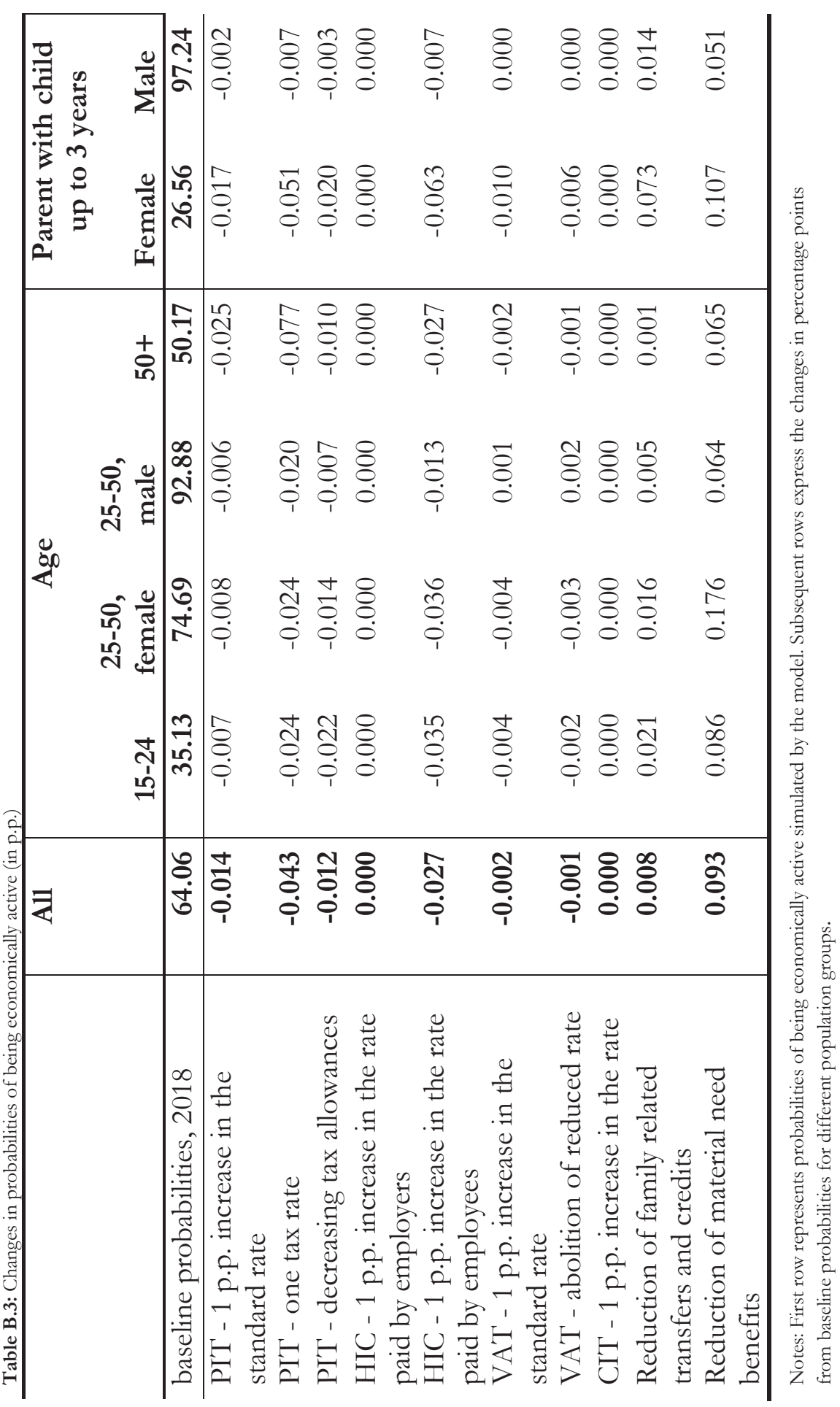




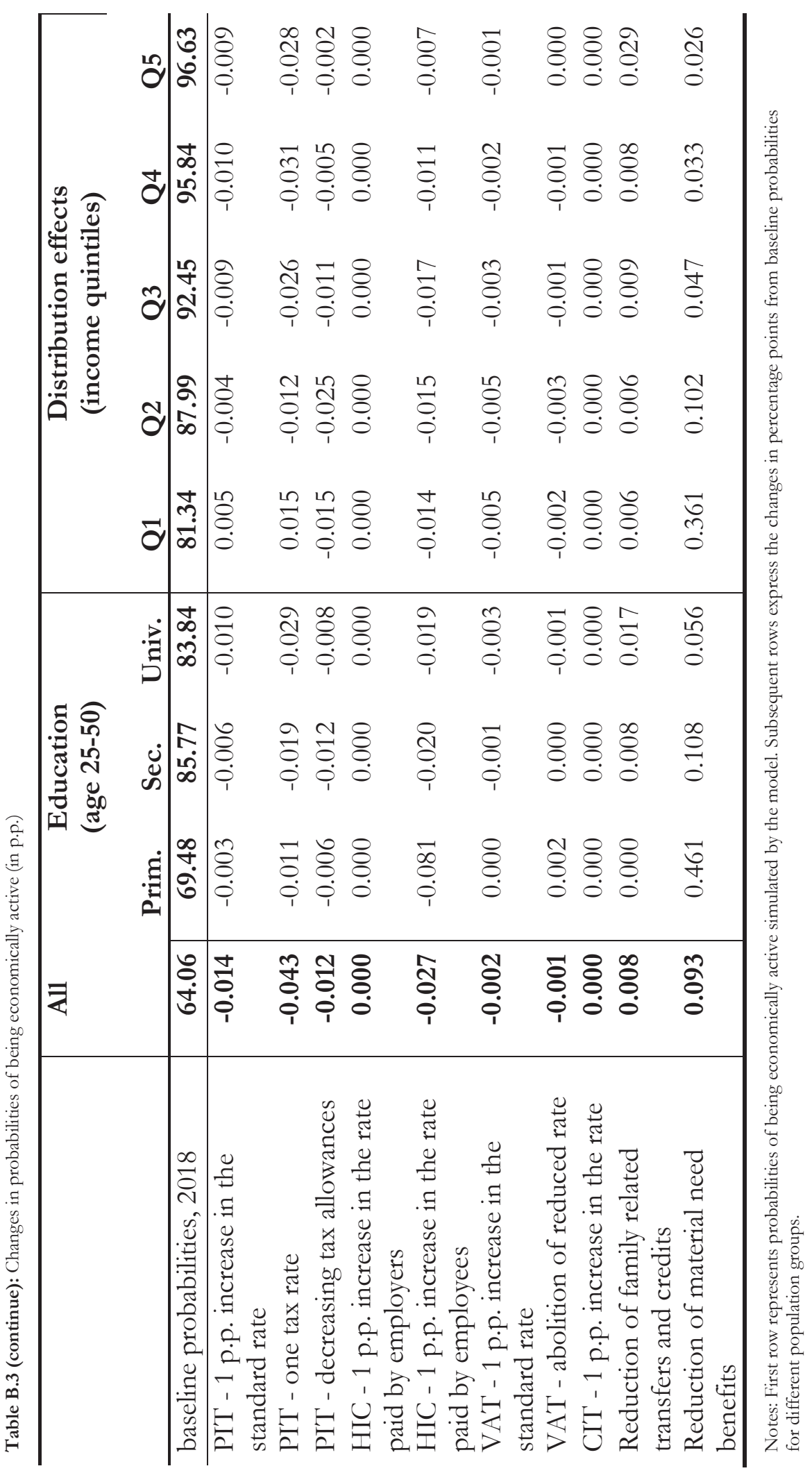




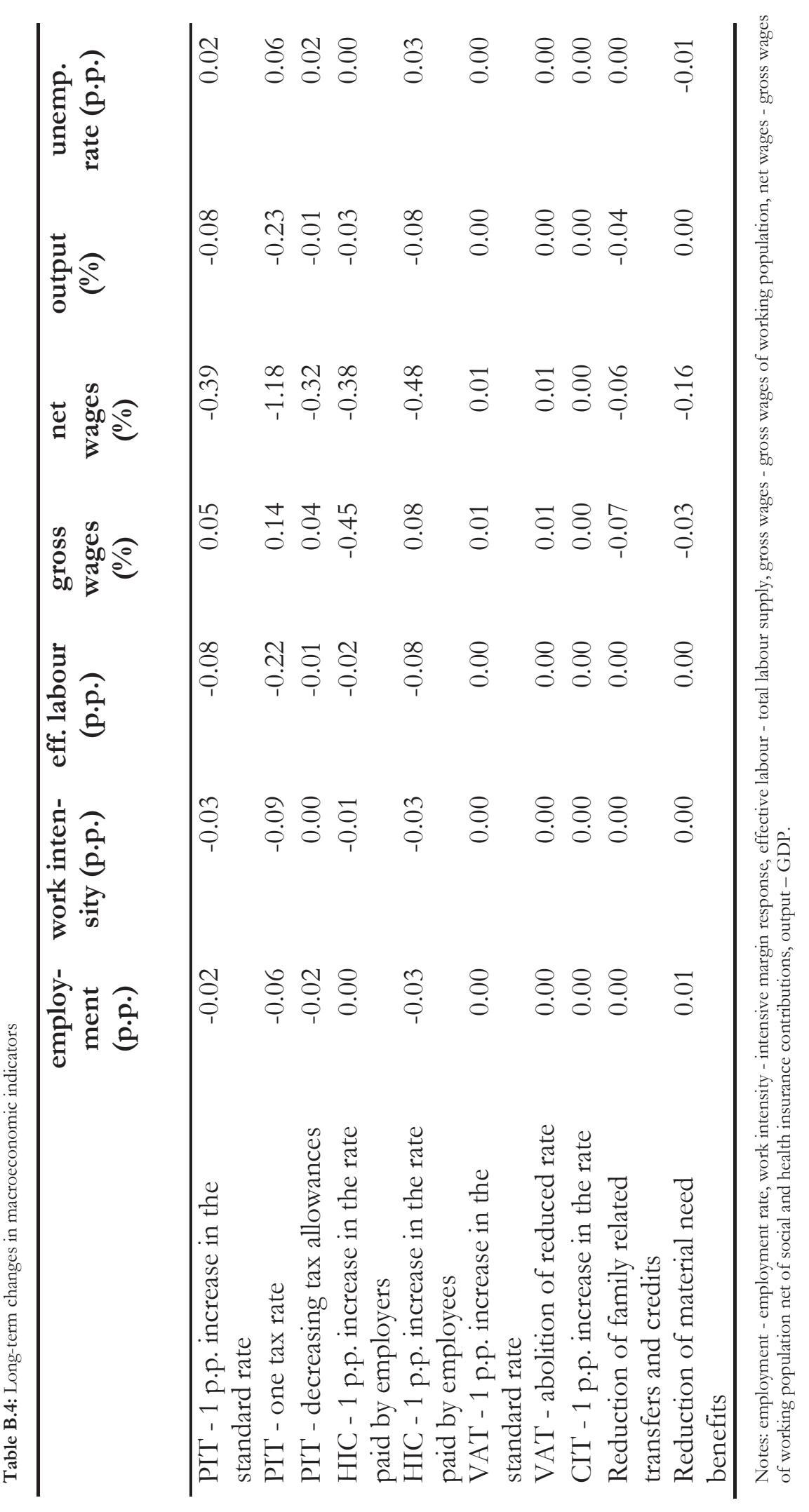




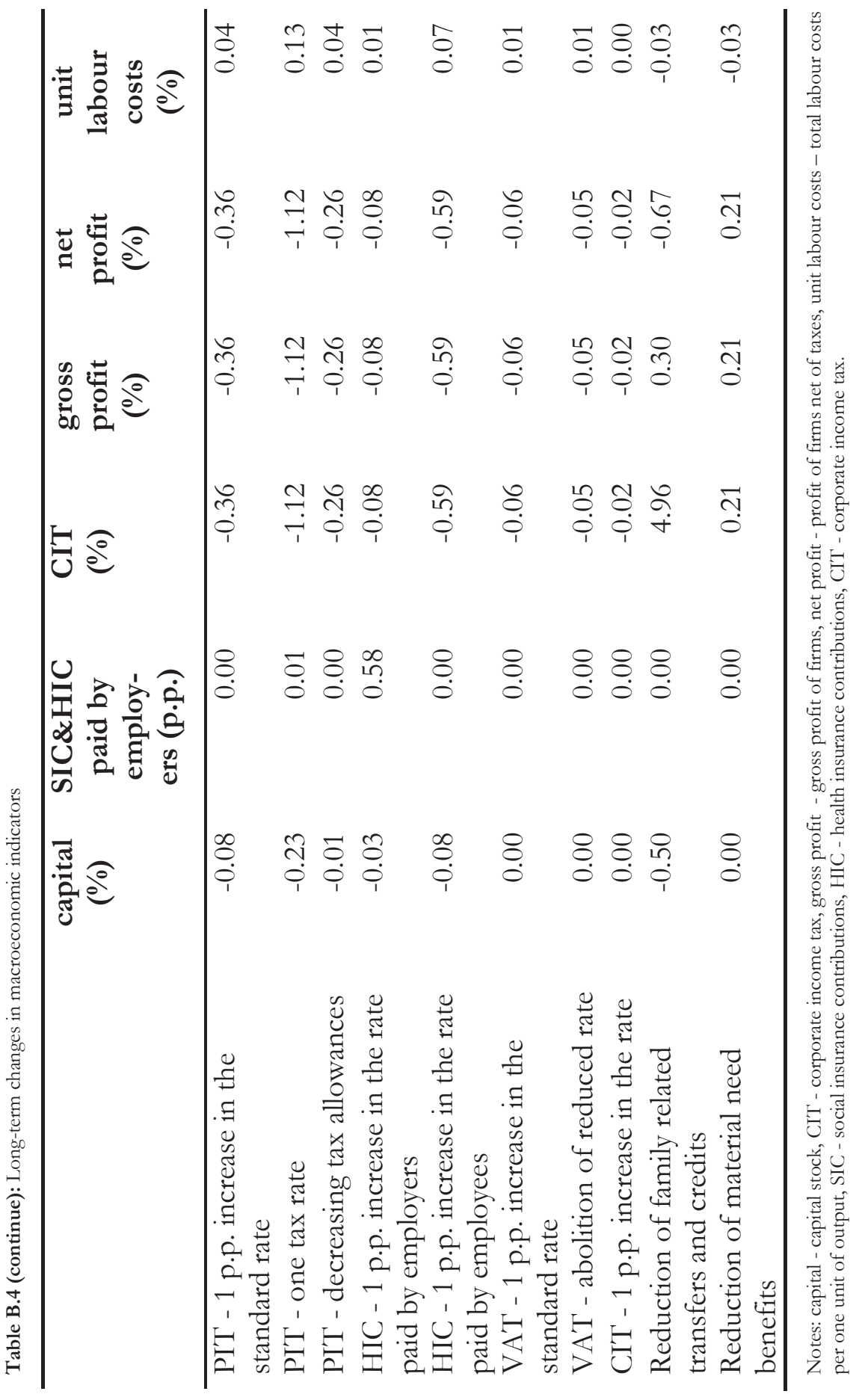


www.celsi.sk

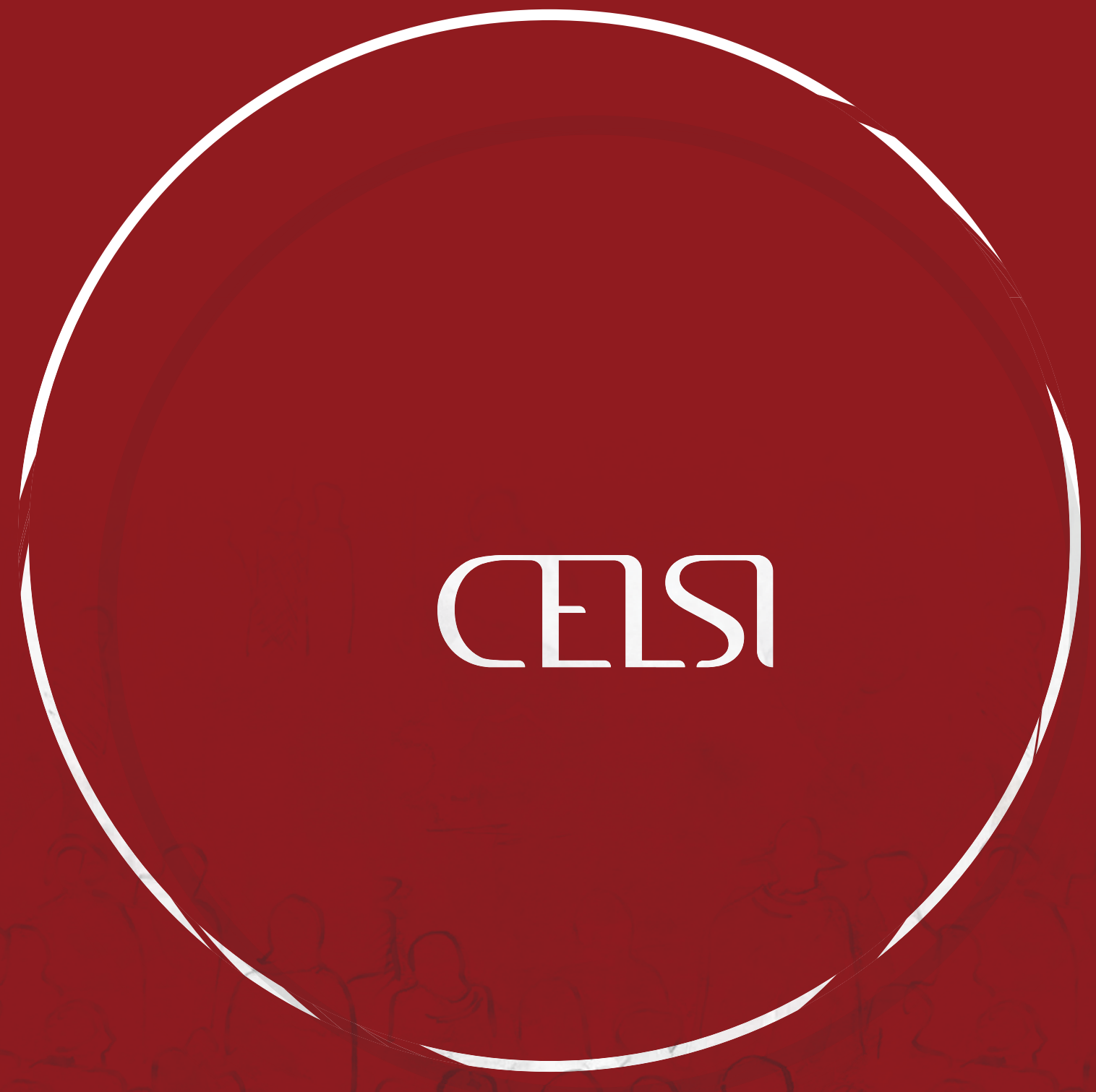

